\title{
Persulfate mediated solar photo-Fenton aiming at wastewater treatment plant effluent improvement at neutral PH: emerging contaminant removal, disinfection, and elimination of antibiotic-resistant bacteria
}

\author{
Maria Clara V. M. Starling ${ }^{1}$ - Elizângela P. Costa ${ }^{1}$ • Felipe A. Souza ${ }^{1}$ - Elayne C. Machado ${ }^{1}$. Juliana Calábria de Araujo ${ }^{1}$. \\ Camila C. Amorim ${ }^{1}$ (1)
}

Received: 28 August 2020 / Accepted: 23 November 2020 / Published online: 4 January 2021

(C) The Author(s) 2021

\begin{abstract}
This work investigated an innovative alternative to improve municipal wastewater treatment plant effluent (MWWTP effluent) quality aiming at the removal of contaminants of emerging concern (caffeine, carbendazim, and losartan potassium), and antibiotic-resistant bacteria (ARB), as well as disinfection (E. coli). Persulfate was used as an alternative oxidant in the solar photo-Fenton process ( $\mathrm{solar} / \mathrm{Fe} / \mathrm{S}_{2} \mathrm{O}_{8}{ }^{2-}$ ) due to its greater stability in the presence of matrix components. The efficiency of solar/ $\mathrm{Fe} / \mathrm{S}_{2} \mathrm{O}_{8}{ }^{2-}$ at neutral $\mathrm{pH}$ using intermittent iron additions is unprecedented in the literature. At first, solar/ $\mathrm{Fe} / \mathrm{S}_{2} \mathrm{O}_{8}{ }^{2-}$ was performed in a solar simulator $\left(30 \mathrm{~W} \mathrm{~m}^{-2}\right.$ ) leading to more than $60 \%$ removal of CECs, and the intermittent iron addition strategy was proved effective. Then, solar $/ \mathrm{Fe} / \mathrm{S}_{2} \mathrm{O}_{8}{ }^{2-}$ and solar $/ \mathrm{Fe} / \mathrm{H}_{2} \mathrm{O}_{2}$ were compared in semi-pilot scale in a raceway pond reactor (RPR) and a cost analysis was performed. Solar/ $/ \mathrm{Fe} / \mathrm{S}_{2} \mathrm{O}_{8}{ }^{2-}$ showed higher efficiencies of removal of target CECs (55\%), E. coli (3 log units), and ARB (3 to 4 log units) within $1.9 \mathrm{~kJ} \mathrm{~L}^{-1}$ of accumulated irradiation compared to solar/ $/ \mathrm{Fe} / \mathrm{H}_{2} \mathrm{O}_{2}(\mathrm{CECs}$, 49\%; E. coli, $2 \log$ units; ARB, 1 to $3 \log$ units in $2.5 \mathrm{~kJ} \mathrm{~L}^{-1}$ ). None of the treatments generated acute toxicity upon Allivibrio fischeri. Lower total cost was obtained using $\mathrm{S}_{2} \mathrm{O}_{8}{ }^{2-}\left(0.6 € \mathrm{~m}^{-3}\right)$ compared to $\mathrm{H}_{2} \mathrm{O}_{2}\left(1.2 € \mathrm{~m}^{-3}\right)$. Therefore, the iron intermittent addition aligned to the use of persulfate is suitable for MWWTP effluent quality improvement at neutral $\mathrm{pH}$.
\end{abstract}

Keywords Photo-Fenton $\cdot$ Raceway pond reactor $\cdot$ Intermittent iron addition $\cdot$ Persulfate $\cdot$ Antimicrobial resistance

\section{Introduction}

As conventional treatment systems used in municipal wastewater treatment plants (MWWTP) are generally not designed to remove contaminants of emerging concern (CECs), MWWTP effluent constitutes one of the main sources of CECs for environmental waters (Ribeiro et al. 2015). The presence of CECs in surface water (ng- $\mu \mathrm{g} \mathrm{L}^{-1}$ ) may lead to

Responsible editor: Vítor Pais Vilar

Camila C. Amorim

camila@desa.ufmg.br

1 Department of Sanitary and Environmental Engineering, Research Group on Environmental Applications of Advanced Oxidative Processes, Universidade Federal de Minas Gerais, UFMG, Presidente Antônio Carlos, 6627, Belo Horizonte, MG 31270-901, Brazil negative impacts to human health as well as to acute and chronic toxicity towards aquatic biota (Barceló 2008). Moreover, CECs have the potential to boost the selection of antibiotic-resistant bacteria (ARB) in natural and engineered environments, such as biological reactors present in MWWTP (Rizzo et al. 2013).

Infections by ARB cause 700,000 deaths annually worldwide (O'Neill 2014), thus being considered one of the main issues regarding public health by the World Health Organization. As ARB are abundant in MWWTP effluent, the implementation of advanced technologies for improving effluent quality has been strongly recommended by environmental and health agencies (Giannakis et al. 2016; Tiedeken et al. 2017). Recent works have evaluated the performance of advanced oxidation processes (AOPs), such as solar photoFenton (solar $/ \mathrm{Fe} / \mathrm{H}_{2} \mathrm{O}_{2}$ ), on the inactivation of ARB (Giannakis et al. 2018, Giannakis 2017; Michael et al. 2019). AOPs' effectiveness on ARB removal is related to 
the formation of highly reactive oxidative radicals (for example: hydroxyl radical, $\mathrm{HO}^{\bullet}$ ), which cause repeated damage to external and internal cell components leading to death (SernaGalvis et al. 2019a).

Among AOPs, solar photo-Fenton (solar $/ \mathrm{Fe}^{2+} / \mathrm{H}_{2} \mathrm{O}_{2}$ ) is of particular interest once it assembles the use of renewable energy with an environmentally safe and cheap reagent (iron, $\mathrm{Fe}^{2+}$ ) in the presence of an ordinary oxidant $\left(\mathrm{H}_{2} \mathrm{O}_{2}\right)$ (Litter et al. 2017; Papić et al. 2009). The regeneration of $\mathrm{Fe}^{3+}$ to $\mathrm{Fe}^{2+}$ occurs faster under solar irradiation than in dark Fenton reactions. Besides, iron species formed in the system (at acidic $\mathrm{pH}$ ) may absorb light in the visible range $(<580 \mathrm{~nm})$ leading to an extra pathway for $\mathrm{OH}^{\bullet}$ formation. Solar photo-Fenton reached $95 \%$ removal of 22 CECs from real MWWTP effluent elsewhere (Klamerth et al. 2013), making this technology especially attractive for post-treatment of this matrix in locations where solar irradiation is abundant (Marcelino et al. 2014).

Among solar reactors used for the application of solar photo-Fenton, the raceway pond reactor (RPR) shows the best cost-benefit when the goal is to remove CEC as it is not necessary to concentrate irradiation for the removal of these contaminants from municipal wastewater treatment plant effluent once they are present in very low concentrations (ng to $\mu \mathrm{g} \mathrm{L}^{-1}$ ). RPR is a low-cost reactor that has been proved successful for the removal of CEC from MWWTP effluent. While costs related to the $\mathrm{CPC}$ reactor reach $400 € \mathrm{~m}^{-2}$, the cost of a RPR, a reactor that is built with cheap material, is estimated to be around $10 € \mathrm{~m}^{-2}$ (Carra et al. 2014; Rivas et al. 2015). Regarding energy power required for wastewater recirculation, CPC uptakes an average of $80 \mathrm{~W} \mathrm{~m}^{-3}$ while RPR employs $4 \mathrm{~W} \mathrm{~m}^{-3}$.

Nevertheless, one of the main limitations of solar photoFenton is the acidic $\mathrm{pH}$ required for optimum efficiency due to limited iron solubility at neutral $\mathrm{pH}$. As a result, efforts have been made to enable the application of photo-Fenton at neutral $\mathrm{pH}$, such as the use of iron complexing agents (i.e., ferrioxalate, EDDS, citric acid, etc.). However, the addition of complexing agents could increase treatment costs, thus discouraging the application of these technologies mainly in developing countries, suitable locations for the employment of solar technologies due to high levels of incident solar irradiation and lack of infrastructure. As an alternative, the intermittent iron addition strategy may be explored to enable solar photo-Fenton process operation at neutral $\mathrm{pH}$ since it guarantees iron availability throughout reaction at higher $\mathrm{pH}(5-8)$. Despite successful results obtained using this strategy for the solar $/ \mathrm{Fe} / \mathrm{H}_{2} \mathrm{O}_{2}$ process (Carra et al. 2013; Clarizia et al. 2017), there are no previous studies investigating its effectiveness using persulfate $\left(\mathrm{S}_{2} \mathrm{O}_{8}{ }^{2}\right)$ as an alternative oxidant.

Considering the scale-up of AOPs using real effluents from MWWTP, real matrix composition represents a challenge for current research, since natural organic matter (NOM) and ions
$\left(\mathrm{Cl}^{-}, \mathrm{HCO}_{3}{ }^{-}, \mathrm{PO}_{4}{ }^{2-}, \mathrm{NO}_{3}{ }^{-}\right)$present in this matrix may act as hydroxyl radical scavengers and cause light attenuation, thus limiting process efficiency (Ribeiro et al. 2019). Hence, the use of alternative oxidants which form selective radicals has gotten attention in the past years. Persulfate emerges as a potential candidate to be used as an alternative oxidant in the photo-Fenton process as it reacts with $\mathrm{Fe}^{2+}$ to form sulfate radical $\left(\mathrm{SO}_{4}{ }^{\bullet-}\right)$ which has a longer lifespan when compared to $\mathrm{OH}^{\bullet}$. Reaction rates between $\mathrm{SO}_{4}{ }^{\bullet-}$, natural organic matter, and ions are lower when compared to rates reported for $\mathrm{OH}^{\bullet}$ (Ahmed et al. 2014; Ahmed and Chiron 2014; Lian et al. 2017; Miralles-Cuevas et al. 2017; Starling et al. 2019b) because $\mathrm{SO}_{4}{ }^{\bullet-}$ reacts only via electron transfer, while $\mathrm{OH}^{\bullet}$ may react via three different mechanisms $(\mathrm{OH}$ addition, hydrogen transfer, and electron transfer). Thus, $\mathrm{SO}_{4}{ }^{\bullet-}$ is more stable for the treatment of real matrices which contain various constituents. In addition, $\mathrm{OH}^{\bullet}$ may be formed simultaneously in the presence of $\mathrm{SO}_{4}{ }^{--}$at the natural pH of MWWTP effluent by the reaction of these radicals with hydroxide ions $\left(\mathrm{OH}^{-}\right)$(Fang et al. 2012; Wang et al. 2017).

Therefore, the aim of this study is to investigate the efficiency of the solar $/ \mathrm{Fe}^{2+} / \mathrm{S}_{2} \mathrm{O}_{8}{ }^{2-}$ process at neutral $\mathrm{pH}$ using the intermittent iron addition strategy for the removal of three model CECs (caffeine (CAF), carbendazim (CBZ), and losartan potassium (LP)), which are highly consumed and frequently detected in environmental compartments (Starling et al. 2019a, 2019b), from real MWWTP effluent. At first, solar $/ \mathrm{Fe}^{2+} / \mathrm{S}_{2} \mathrm{O}_{8}{ }^{2-}$ was applied in a solar simulator. Then, solar $/ \mathrm{Fe}^{2+} / \mathrm{S}_{2} \mathrm{O}_{8}{ }^{2-}$ and solar $/ \mathrm{Fe}^{2+} / \mathrm{H}_{2} \mathrm{O}_{2}$ were compared in semipilot scale with regard to CECs and ARB removal, disinfection, and acute toxicity. A cost-benefit analysis was also performed to estimate costs associated to each treatment alternative.

\section{Materials and methods}

\section{Chemicals}

LP, CAF, and CBZ were purchased from Sigma-Aldrich. Table S1 (Supplementary Material) shows the chemical structures and physicochemical properties of each CEC. Hydrogen peroxide and sodium persulfate were purchased from MERCK. Sodium metavanadate and ascorbic acid were purchased from Synth. Bovine serum catalase, methanol, and formic acid were purchased from Sigma-Aldrich $(\geq 98 \%$ purity).

\section{Sampling}

Real MWWTP effluent was sampled after a conventional activated sludge system in a MWWTP located in Belo Horizonte, in the southeast of Brazil, which receives 
wastewater from 1.5 million inhabitants $\left(290 \mathrm{~m}^{3}\right.$ day $\left.^{-1}\right)$, including hospitals, industries, etc. There is no disinfection stage following the biological process in this treatment plant. Real MWWTP effluent was characterized as according to physicochemical parameters as shown in Table S2 (APHA 2012). Samples \#1 and \#2 were used for experiments performed in laboratory scale, and sample \#3 for semi-pilot scale experiments. Acute toxicity was only assessed for sample \#3 as this analysis was only performed for experiments conducted in semi-pilot scale (ISO 2007). Real MWWTP effluent samples were spiked with $100 \mu \mathrm{g} \mathrm{L}^{-1}$ of each target CEC (caffeine (CAF), carbendazim (CBZ), and losartan potassium (LP)) prior to experiments in order to enable proper quantification of target compounds in this matrix before and after proposed treatments. Since total inorganic carbon (TIC) in the nontreated effluent samples was below $50 \mathrm{mg} \mathrm{L}^{-1}$ (Table S2), a concentration which partially avoids the scavenger effect of bicarbonates (Esteban García et al. 2018), no carbonate removal stage was carried out prior to photo-Fenton reactions conducted at neutral $\mathrm{pH}$.

\section{Quantification of target CECs in MWWTP effluent}

Identification and quantification of CECs spiked to MWWTP effluent were performed using an ultra high-pressure liquid chromatographer (UHPLC; Shimadzu) system connected to a QTOF mass spectrometer (Bruker Daltonics, Impact II). Samples were filtered in $0.22-\mu \mathrm{m}$ PVDF membranes prior to injection. The UV detector of the UHPLC was set at $240 \mathrm{~nm}$. A $\mathrm{C}_{18}$ column (Agilent PoroshellHPH-C18 $4.6 \times 150 \mathrm{~mm}$, $2.7 \mu \mathrm{M}$ ) was used with the following mobile phases: (A) methanol acidified with $0.1 \%$ formic acid and (B) water acidified with $0.1 \%$ formic acid at $0.25 \mathrm{~mL} \mathrm{~min}^{-1}$. Sixty percent of A was used until up to $8 \mathrm{~min}$, the rate of A increased to $90 \%$ until $10 \mathrm{~min}$, and the run proceeded in this condition until 20 min. Retention times were $6.4 \mathrm{~min}$ for CBZ (LOD, $0.58 \mu \mathrm{g} \mathrm{L}^{-1}$; LOQ, $1.94 \mu \mathrm{g} \mathrm{L}^{-1}$ ), $6.8 \mathrm{~min}$ for CAF (LOD, $1.33 \mu \mathrm{g} \mathrm{L}^{-1}$; LOQ, $2.92 \mu \mathrm{g} \mathrm{L}^{-1}$ ), and $15 \mathrm{~min}$ for LP (LOD, $0.71 \mu \mathrm{g} \mathrm{L}^{-1}$; LOQ, $2.38 \mu \mathrm{g} \mathrm{L}^{-1}$ ). The QTOF mass spectrometer was operated at positive ionization under the following conditions during all runs: capillary $4500 \mathrm{~V}$, nebulizer 0.4 bar, drying gas $5 \mathrm{~L} \mathrm{~min}^{-1}$, and gas temperature $180{ }^{\circ} \mathrm{C}$ which enabled the detection of nearly $99 \%$ removal for all target compounds by monitoring the following ions: 195, 192, and $423 \mathrm{~m} / \mathrm{z}$ as shown in Fig. S1.

\section{Biological assays}

Acute toxicity of samples was analyzed using the Microtox® device (Model 500 Analyzer SDI, Azur Environmental), which assesses the sensibility of luminescent marine bacteria Allivibrio fischeri exposed to samples (ISO 2007). Luminescence was measured after 5, 15, and $30 \mathrm{~min}$ of exposure to non-treated and treated samples in different dilutions, and $\mathrm{EC}_{50}$ was obtained by statistical analysis of data performed by using the MicrotoxOmni ${ }^{\circledR}$ Software (81.9\% basic test). Results were converted to acute toxicity unit (a.T.u.) as according to Eq. 1. As the highest concentration assessed in the test is $81.9 \%$ which corresponds to 1.22 a.T.u., this is the threshold of this analysis. Therefore, only a.T.u. values above 1.22 are considered toxic.

a.T.u. $=100 / \mathrm{EC}_{50}$

Disinfection was assessed by quantifying Escherichia coli present in the MWWTP effluent before $\left(10^{-6} \mathrm{NMP} / 100 \mathrm{~mL}\right)$ (Table S2) and after proposed treatments by using Colilert kits from IDEXX (Method $9223 \mathrm{~A}$ ) as according to manufacturer instructions and the Standard Methods (APHA 2012).

The spread plate method was applied for the assessment of ARB inherent to MWWTP effluent and in samples withdrawn (10 mL) after solar $/ \mathrm{Fe} / \mathrm{S}_{2} \mathrm{O}_{8}{ }^{2-}$, solar $/ \mathrm{Fe} / \mathrm{H}_{2} \mathrm{O}_{2}$, and controls (solar disinfection, $\mathrm{Fe} / \mathrm{H}_{2} \mathrm{O}_{2}$, and $\mathrm{Fe} / \mathrm{S}_{2} \mathrm{O}_{8}{ }^{2-}$ ). The initial concentration of ARB varied as according to the antibiotic ranging from $10^{-2}$ to $10^{-4} \mathrm{UFC} / 100 \mathrm{~mL}$. Quenching agents (catalase or ascorbic acid) were added to samples submitted to oxidative treatments prior to plating for residual oxidant consumption. Plates containing plate count agar (PCA) alone were used for the quantification of total heterotrophic bacteria (THB). For the analysis of ARB, PCA was supplemented with 10 different antibiotics: ampicillin (AMP, $32 \mathrm{mg} \mathrm{L}^{-1}$ ), chloramphenicol (CLO, $32 \mathrm{mg} \mathrm{L}^{-1}$ ), tetracycline (TET, $16 \mathrm{mg} \mathrm{L}^{-1}$ ), erythromycin (ERY, $32 \mathrm{mg} \mathrm{L}^{-1}$ ), amoxicillin (AMO, $32 \mathrm{mg} \mathrm{L}^{-1}$ ), sulfadiazine (INE, $51.2 \mathrm{mg} \mathrm{L}^{-1}$ ), sulfamethoxazole (AZOLE, $35 \mathrm{mg} \mathrm{L}^{-1}$ ), trimethoprim (TRI, $4 \mathrm{mg} \mathrm{L}^{-1}$ ), ciprofloxacin (CIP, $32 \mathrm{mg} \mathrm{L}^{-1}$ ), and trimethoprim + sulfamethoxazole (TRI + AZOLE, $35 \mathrm{mg} \mathrm{L}^{-} 1$ of each). The concentration and selection of each of these antibiotics were defined as according to the following references (Brooks et al. 2007; Novo et al. 2013; Novo and Manaia 2010; Pei et al. 2006; Yuan et al. 2015). After sample spreading, plates were incubated for 5 days $\left(48 \mathrm{~h}\right.$ at $37^{\circ} \mathrm{C}$, followed by $72 \mathrm{~h}$ at $\left.27^{\circ} \mathrm{C}\right)$ for colony development and the number of colony-forming units (CFU) was counted in each plate within 48 and $120 \mathrm{~h}$, as according to standard procedures (Brooks et al. 2007; Munir et al. 2011).

\section{Photo-Fenton treatment at laboratory scale}

Solar $/ \mathrm{Fe}^{2+} / \mathrm{S}_{2} \mathrm{O}_{8}{ }^{2-}$ assays were conducted in a solar simulator chamber (SUNTEST $\mathrm{CPS}^{+}$, ATLAS) equipped with a xenon lamp using the irradiance range set at $268 \mathrm{~W} \mathrm{~m}^{-2}$ (330 to $800 \mathrm{~nm}$ ) (Fig. S2). $\mathrm{S}_{2} \mathrm{O}_{8}{ }^{2-}$ was added as $\mathrm{Na}_{2} \mathrm{~S}_{2} \mathrm{O}_{8}$ (Merck). Experimental conditions tested in this scale are detailed in Table 1. All reactions were conducted in batch and in duplicates in a $400-\mathrm{mL}$ glass recipient placed inside the solar 
Table 1 Experimental conditions tested for the solar $/ \mathrm{Fe}^{2+} / \mathrm{S}_{2} \mathrm{O}_{8}{ }^{2-}$ process at neutral $\mathrm{pH}$, reference experiments $(\mathrm{pH} 3)$ and controls carried out in a solar chamber

\begin{tabular}{|c|c|c|c|c|c|c|c|}
\hline \multirow[t]{2}{*}{ Type } & \multirow[t]{2}{*}{ Name } & \multicolumn{2}{|l|}{$\mathrm{Fe}^{2+}$} & \multicolumn{2}{|l|}{$\mathrm{S}_{2} \mathrm{O}_{8}{ }^{2-}$} & \multirow[t]{2}{*}{ Fe addition } & \multirow[t]{2}{*}{$\mathrm{pH}$} \\
\hline & & $\mathrm{mg} \mathrm{L}^{-1}$ & $\mathrm{mM}$ & $\mathrm{mg} \mathrm{L}^{-1}$ & $\mathrm{mM}$ & & \\
\hline \multirow[t]{10}{*}{ Assay } & $\# 1$ & 2.7 & 0.05 & 57.6 & 0.3 & Single & \multirow[t]{6}{*}{7} \\
\hline & $\# 2$ & 2.7 & 0.05 & 288.2 & 1.5 & Single & \\
\hline & \# 3 & 27.5 & 0.5 & 57.6 & 0.3 & $2 x(10)+3 x(2.5)$ & \\
\hline & $\# 4$ & 27.5 & 0.5 & 288.2 & 1.5 & $2 \mathrm{x}(10)+3 \mathrm{x}(2.5)$ & \\
\hline & \# 5 & 27.5 & 0.5 & 57.6 & 0.3 & Single & \\
\hline & \# 6 & 27.5 & 0.5 & 288.2 & 1.5 & Single & \\
\hline & $\# 7$ & 2.7 & 0.05 & 57.6 & 0.3 & Single & \multirow[t]{4}{*}{3} \\
\hline & $\# 8$ & 2.7 & 0.05 & 288.2 & 1.5 & Single & \\
\hline & \# 9 & 27.5 & 0.5 & 57.6 & 0.3 & Single & \\
\hline & \# 10 & 27.5 & 0.5 & 288.2 & 1.5 & Single & \\
\hline \multirow[t]{7}{*}{ Control } & Dark Fenton 1 & 2.7 & 0.05 & 57.6 & 0.3 & Single & \multirow[t]{7}{*}{7} \\
\hline & Dark Fenton 2 & 27.5 & 0.5 & 288.2 & 1.5 & Single & \\
\hline & Coagulation 1 & 2.7 & 0.05 & - & - & Single & \\
\hline & Coagulation 1 & 27.5 & 0.5 & - & - & Single & \\
\hline & Solar only & - & - & - & - & - & \\
\hline & Solar $/ \mathrm{S}_{2} \mathrm{O}_{8}{ }^{2-}$ & - & - & 57.6 & 0.3 & - & \\
\hline & Solar $/ \mathrm{S}_{2} \mathrm{O}_{8}{ }^{2-}$ & - & - & 288.2 & 1.5 & - & \\
\hline
\end{tabular}

- none

chamber for $60 \mathrm{~min}$. A magnetic stirrer was placed below the solar chamber, and reactions were conducted under continuous stirring $(150 \mathrm{rpm})$ by a magnetic bar placed inside the glass recipient. The original pH of MWWTP effluent, 6.67.5 (Table S2), was adjusted to 7 prior to assays \#1 to 6 . Single and fractioned iron additions were tested for comparison purposes. Assays \#7 to 10 were conducted as reference experiments at $\mathrm{pH} 3$ as this is the optimum $\mathrm{pH}$ for the operation of Fenton reactions due to increased iron solubility at acidic $\mathrm{pH}$. $\mathrm{pH}$ was adjusted by adding $\mathrm{HCl}$ to samples (1 mM).

Experiments were performed using two different initial $\mathrm{Fe}^{2+}$ concentrations: $2.7 \mathrm{mg} \mathrm{L}^{-1}$ (minimum) and $27.5 \mathrm{mg} \mathrm{L}^{-1}$ (maximum). Final $\mathrm{Fe}^{2+}$ concentrations were always below $5 \mathrm{mg} \mathrm{L}^{-1}$ after all experiments. Persulfate concentrations ranged from $57.6 \mathrm{mg} \mathrm{L}^{-1}(0.3 \mathrm{mM})$ to $288.2 \mathrm{mg} \mathrm{L}^{-1}(1.5 \mathrm{mM})$, which are equivalent to concentrations applied in studies published using solar $/ \mathrm{Fe}^{2+} / \mathrm{S}_{2} \mathrm{O}_{8}{ }^{2-}$ for the removal of CECs from MWWTP effluent (Ahmed et al. 2014; Ahmed and Chiron 2014; Miralles-Cuevas et al. 2017). Samples were withdrawn during reactions for the quantification of residual iron (dissolved $\mathrm{Fe}^{2+}$, total $\mathrm{Fe}$ ), residual persulfate (ISO 1998; Liang et al. 2008), CECs, and chemical oxygen demand (COD). Ascorbic acid solution was added to samples for the consumption of residual $\mathrm{S}_{2} \mathrm{O}_{8}{ }^{2-}$ (OlmezHanci et al. 2014). Control experiments consisted of dark Fenton-like $\left(\mathrm{Fe}^{2+} / \mathrm{S}_{2} \mathrm{O}_{8}{ }^{2-}\right)$, $\mathrm{Fe}$ alone, and solar irradiation alone or with each oxidant (Table 1). Accumulated irradiation per unit of sample volume $\left(Q_{\mathrm{UV}} ; \mathrm{kJ} \mathrm{L}^{-1}\right)$ during bench scale experiments was calculated as according to Eqs. 2 and 3. Constant average incident irradiation $\mathrm{UV}_{\mathrm{G}, \mathrm{n}}\left(\mathrm{W} \mathrm{m}^{-2}\right)$ was equivalent to $30 \mathrm{~W} \mathrm{~m}^{-2} ; Q_{\mathrm{UV}, \mathrm{n}}$ is the energy accumulated from the beginning of the reaction up to each sampling time, $\operatorname{Vr}(\mathrm{L})$ is reactor total volume $(400 \mathrm{~mL})$, and $\operatorname{Ar}\left(\mathrm{m}^{2}\right)$ is the irradiated surface area (Malato et al. 2009).

$Q_{\mathrm{UV}, \mathrm{n}}=\mathrm{Q}_{\mathrm{UV}, n-1}+\Delta t \cdot \mathrm{UV}_{\mathrm{G}, \mathrm{n}} \cdot(\mathrm{Ar} / \mathrm{Vr})$

$\Delta t=t_{n}-t_{n-1}$

\section{Photo-Fenton at semi-pilot scale}

Solar $/ \mathrm{Fe}^{2+} / \mathrm{S}_{2} \mathrm{O}_{8}{ }^{2-}$ treatment of MWWTP effluent at neutral $\mathrm{pH}$ using the intermittent iron addition strategy was also conducted in semi-pilot scale in a raceway pond reactor (RPR) (Fig. S2) located at the Engineering School (UFMG), in Belo Horizonte, Brazil $\left(19^{\circ} \mathrm{S}, 43^{\circ} \mathrm{W}\right)$. The RPR used in this study has a maximum volume of $28 \mathrm{~L}$ (12 cm liquid depth), and experiments were performed in batch using a total volume of $12 \mathrm{~L}$ (5 cm liquid depth). The reactor contains a paddle wheel to provide for sample mixing during reactions. Incident solar irradiation $\left(\mathrm{W} \mathrm{m}^{-2}\right)$ was measured throughout reactions by using a global UV radiometer (CUV 5 Kipp\&Zonen; 290$400 \mathrm{~nm}$ range, $264 \mathrm{mV} \mathrm{W}^{-1}$ sensibility), which was positioned horizontally to enable the calculation of accumulated UV irradiation $\left(Q_{\mathrm{UV}}\right)$ per volume of sample (L) as according to Eqs. 2 and 3 (Malato et al. 2009). Average incident irradiation $\left(\mathrm{UV}_{\mathrm{G}, \mathrm{n}} ; \mathrm{W} \mathrm{m}{ }^{-2}\right)$ during these experiments was 
calculated considering natural incident irradiation values measured by the radiometer. A reaction in the presence of $\mathrm{H}_{2} \mathrm{O}_{2}$ was also performed under similar conditions for comparison purposes.

MWWTP effluent $\mathrm{pH}$ was adjusted to 7 prior to each experiment using $\mathrm{HCl}(1 \mathrm{mM}) .288 .2 \mathrm{mg} \mathrm{L}^{-1} \mathrm{~S}_{2} \mathrm{O}_{8}{ }^{2-}$ was used for the solar/ $/ \mathrm{Fe} / \mathrm{S}_{2} \mathrm{O}_{8}{ }^{2-}$, and the equivalent in moles of $\mathrm{H}_{2} \mathrm{O}_{2}$ was applied for the solar/Fe/ $/ \mathrm{H}_{2} \mathrm{O}_{2}$ process $\left(50 \mathrm{mg} \mathrm{L}^{-1}\right.$ of $\mathrm{H}_{2} \mathrm{O}_{2}$ ). Residual hydrogen peroxide concentration was quantified by the metavanadate method (Nogueira et al. 2005). $\mathrm{Fe}^{2+}$ was added intermittently during treatment $(0,5,10,15$, and $20 \mathrm{~min}$ ), and the final concentration was equivalent to $55 \mathrm{mg} \mathrm{L}^{-1}$ for both systems as according to previous studies (Ahmed et al. 2014). Experiments were performed in duplicates using real MWWTP effluent sample \#3 (Table S2). Acute toxicity, disinfection (E. coli), and CECs were quantified during treatments. Catalase enzyme $\left(460 \mathrm{mg} \mathrm{L}^{-1}\right.$ in phosphate buffer) (Poole 2004) or ascorbic acid solutions were added to samples to interrupt reactions as quenching agents to $\mathrm{H}_{2} \mathrm{O}_{2}$ and $\mathrm{S}_{2} \mathrm{O}_{8}{ }^{2-}$, respectively, which do not affect sample acute toxicity (Olmez-Hanci et al. 2014).

\section{Cost-benefit analysis}

Cost-benefit analysis was performed considering conditions tested in the semi-pilot scale. The methodology used for the cost analysis was adapted from Miralles-Cuevas et al. (2017). According to this methodology, the total cost (TC) related to the application of a technology (TC, $€ \mathrm{~m}^{-3}$ ) refers to (i) amortization cost (AC) of the reactor and other equipment, (ii) operational costs (OC), and total volume to be treated per year $\left(V_{\mathrm{t}} ; \mathrm{m}^{3}\right)($ Eq. 4)

$\mathrm{TC}\left(€ \mathrm{~m}^{-3}\right)=(\mathrm{AC}+\mathrm{OC}) / V_{\mathrm{T}}$

AC was calculated considering $7.5 \%$ of the interest rate (BRASIL 2017) in the investment cost and a plant life-time period equivalent to 20 years. The main cost of solar technologies is related to total irradiated surface area which varies according to accumulated UV energy $\left(Q_{\mathrm{UVG}}\right)$. $Q_{\mathrm{UVG}}$ is calculated in relation to the average incident solar UV irradiation in a location $\left(\mathrm{UV}_{\mathrm{G}}\right)$ and to the number of hours of operation in a year $\left(H_{\mathrm{s}}=12 \mathrm{~h} * 365\right)$. Therefore, the surface area for solar $\left(S_{\mathrm{S}}\right)$ irradiated reactors may be calculated as follows (Eqs. 5 and 6):

$S_{\mathrm{S}}=\left(Q_{\mathrm{UVG}} * V_{\mathrm{T}} / H_{\mathrm{s}} * \mathrm{UV} \mathrm{G}_{\mathrm{G}}\right)$

where $S_{\mathrm{S}}$ is the surface area required for the solar system, $Q_{\mathrm{UVG}}\left(\mathrm{kJ} \mathrm{L}^{-1}\right)$ is the amount of accumulated energy required to remove $50 \%$ of total CEC in each process, $V_{\mathrm{T}}(\mathrm{L})$ is the total volume of wastewater treated in a year, $H_{\mathrm{s}}$ is the total number of hours of operation in a year, and $\mathrm{UV}_{\mathrm{G}}$ is the average local global irradiation ( $30 \mathrm{~W} \mathrm{~m}^{-2}$ in Belo Horizonte, $\mathrm{MG}$, Brazil).
Fifty percent removal was chosen as the minimum removal rate considering results obtained in semi-pilot scale.

Once surface area is determined, investment costs may be defined as according to Eq. 6, where $C_{\mathrm{b}}$ corresponds to the cost of the reactor with a surface area $S_{\mathrm{S}}$. Considering that total cost per area of the RPR reactor is 40 times lower than costs calculated for CPC (Carra et al. 2014), the cost of an RPR with a surface area of $1000 \mathrm{~m}^{2}$ (SRPR) is estimated to be $12,090 €$ $\left(S_{\mathrm{b}}\right)$ (Water 2016; Miralles-Cuevas et al. 2017).

$\mathrm{ICS}=C_{\mathrm{b}} *\left(S_{\mathrm{S}} / S_{\mathrm{b}}\right)$

Reagent prices and electricity costs detailed in Table S3 were used to calculate operational costs (OC). Costs related to each reagent were calculated considering the dose of each reagent to be applied per cubic meter of MWWTP effluent. In addition, a total volume of $1000 \mathrm{~m}^{3}$ day $^{-1}$ was used in calculations.

\section{Results and discussion}

\section{Solar/Fe/ $\mathrm{S}_{\mathbf{2}} \mathbf{O}_{\mathbf{8}}{ }^{2-}$ : laboratory scale}

Although previous studies have investigated the efficiency of the solar $/ \mathrm{Fe} / \mathrm{S}_{2} \mathrm{O}_{8}{ }^{2-}$ at acidic $\mathrm{pH}$ for the removal of CECs (Ahmed and Chiron 2014; Miralles-Cuevas et al. 2017), to this date, there are no works on the application of this treatment at neutral $\mathrm{pH}$ using the intermittent iron addition strategy, as proposed in this study. Figure 1 shows removal of CECs (Fig. 1a-c), final $\mathrm{pH}$ values, and COD removal (Fig. 1d) obtained after all tested conditions and controls. Dissolved $\mathrm{Fe}^{2+}$ concentration and oxidant consumption during assays are shown in Fig. S3 (A, B, C, D).

$\mathrm{CAF}$ removal was equivalent to $62 \%$ during assay \#2 (2.7 $\mathrm{mg} \mathrm{L}^{-1}$ of $\mathrm{Fe}^{2+}$ and $282.2 \mathrm{mg} \mathrm{L}^{-1} \mathrm{~S}_{2} \mathrm{O}_{8}{ }^{2-}$ ) conducted at neutral $\mathrm{pH}$ (Fig. 1a). Meanwhile, $\mathrm{Fe} / \mathrm{S}_{2} \mathrm{O}_{8}{ }^{2-}$ using 10 times more $\mathrm{Fe}^{2+}\left(27 \mathrm{mg} \mathrm{L}^{-1}\right)$ reached the same efficiency $(61 \%$ removal), confirming the occurrence of photo-Fenton reactions instead of dark Fenton alone in the irradiated system, since lower concentrations of reagents were required under irradiation. Solar irradiation alone led to $39 \%$ CAF removal (Fig. 1a), indicating indirect photolysis of CAF via radical formation by photolysis of dissolved organic matter and nitrate ions present in the MWWTP effluent, as observed by Wang et al. (2017).

Regarding the removal of $\mathrm{CBZ}$ at neutral $\mathrm{pH}$, assay \#4 performed with the highest reagent concentrations and intermittent iron additions, as well as its equivalent $\mathrm{Fe} / \mathrm{S}_{2} \mathrm{O}_{8}{ }^{2-}$ conducted in the dark (Fenton 2 ) both reached $>80 \%$ efficiency compared to a maximum of $60 \%$ obtained with a single iron addition (Fig. 1b). These results indicate that continuous availability of iron contributed to appropriate removal of CBZ 
in these systems. As shown by dissolved $\mathrm{Fe}^{2+}$ and $\mathrm{S}_{2} \mathrm{O}_{8}{ }^{2-}$ consumption profiles (Fig. S3 D), dissolved $\mathrm{Fe}^{2+}$ concentration was low $\left(<2.5 \mathrm{mg} \mathrm{L}^{-1}\right)$ during the entire reaction in assay $\# 4$, and no increase was observed after intermittent iron additions. This occurs due to $\mathrm{Fe}^{2+}$ conversion to $\mathrm{Fe}^{3+}$ after reacting with $\mathrm{S}_{2} \mathrm{O}_{8}{ }^{2-}$ as $\mathrm{Fe}^{2+}$ concentration remained low in the system even after the addition of this catalyst. Similar observations were made by Carra et al. (2013) when applying this strategy using $\mathrm{H}_{2} \mathrm{O}_{2}$ as an oxidant (Carra et al. 2013), as $\mathrm{Fe}^{2+}$ quickly reacted with the oxidant after intermittent additions.

Despite high efficiency observed for CBZ removal by solar $/ \mathrm{Fe} / \mathrm{S}_{2} \mathrm{O}_{8}{ }^{2-}$, control experiments conducted with iron alone led to $50 \% \mathrm{CBZ}$ removal. This suggests that CBZ may make complexes and precipitate with iron at neutral $\mathrm{pH}$, as it has been observed for CBZ and other CECs (Costa et al. 2019; Norte et al. 2018). This phenomenon may also have occurred in dark $\mathrm{Fe} / \mathrm{S}_{2} \mathrm{O}_{8}{ }^{2-}$ reactions simultaneously with $\mathrm{CBZ}$ degradation by sulfate radicals as $40 \%$ of $\mathrm{S}_{2} \mathrm{O}_{8}{ }^{2-}$ were consumed during this assay (Fig. S3 D).

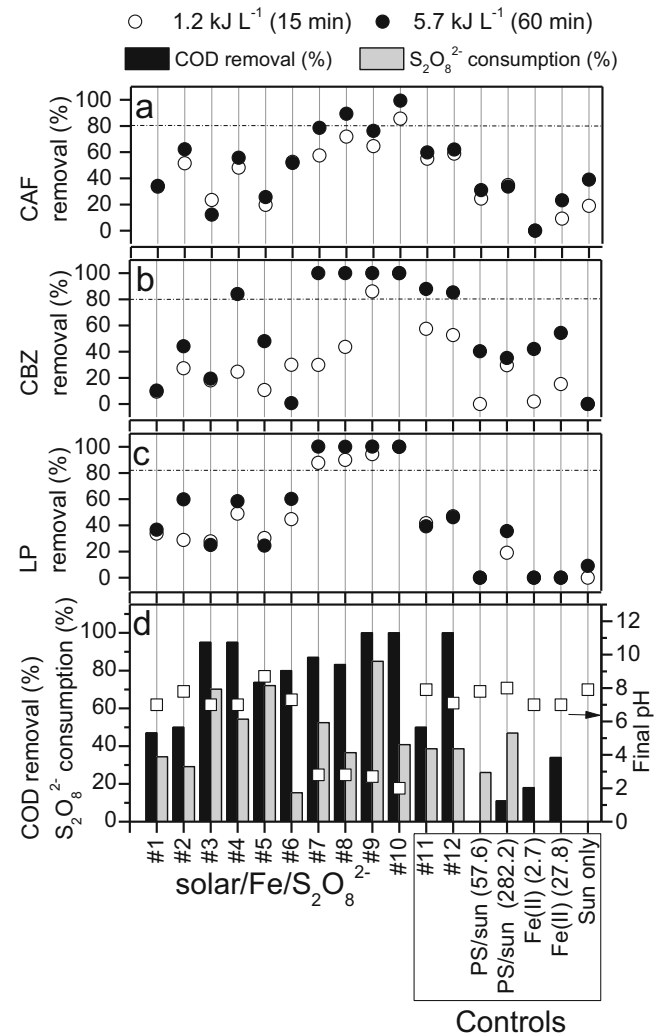

Fig. 1 Removal of a CAF, b CBZ, and $\mathbf{c}$ LP (III) after $15\left(1.2 \mathrm{~kJ} \mathrm{~L}^{-\mathbf{1}}\right)$ and $60 \mathrm{~min}\left(5.7 \mathrm{~kJ} \mathrm{~L}^{-\mathbf{1}}\right)$ of reaction, and $\mathbf{d}$ final COD removal, oxidant consumption, and $\mathrm{pH}$ via for solar $/ \mathrm{Fe} / \mathrm{S}_{2} \mathrm{O}_{8}{ }^{2-}$ experiments at neutral and acidic $\mathrm{pH}$ (reference experiments) and controls conducted in a solar simulator. Respective $\mathrm{Fe}^{2+}: \mathrm{S}_{2} \mathrm{O}_{8}{ }^{2-}$ concentration $\left(\mathrm{mg} \mathrm{L}^{-1}\right)$ at $\mathrm{pH}=7.0$, for single $\mathrm{Fe}$ addition: \#1 (2.7:57.6), \#2 (2.7:288.2), \#5 (27.5:57.6), and \#6 $(27.5: 288.2)$ and for intermittent Fe addition: \#3 (27.5:57.6) and \#4 (27.5:288.2). At $\mathrm{pH}=3.0$ : \#7 (2.7:57.6), \#8 (2.7:288.2), \#9 (27.5:57.6), and $\# 10(27.5: 288.2)$. Dark control at $\mathrm{pH}=7.0$ with single \#11 (27.5:288.2) and intermittent Fe addition \#12 (27.5:288.2)
When it comes to $\mathrm{LP}$, solar $/ \mathrm{Fe} / \mathrm{S}_{2} \mathrm{O}_{8}{ }^{2-}$ conducted at neutral $\mathrm{pH}$ reached $60 \%$ removal in one hour $\left(5.7 \mathrm{~kJ} \mathrm{~L}^{-1}\right)$ (assays \#2, 4, and 6) (Fig. 1c). LP susceptibility to sulfate radical was also reported in a previous study under UV-C/ $\mathrm{S}_{2} \mathrm{O}_{8}{ }^{2-}$ (Starling et al. 2019b). Solar $/ \mathrm{S}_{2} \mathrm{O}_{8}{ }^{2-}$ conducted as a control using the highest concentration of $\mathrm{S}_{2} \mathrm{O}_{8}{ }^{2-}$ led to $35 \%$ LP (60 min; $5.7 \mathrm{~kJ} \mathrm{~L} \mathrm{~L}^{-1}$ ) removal and $32 \%$ removal of all target CECs $\left(60 \mathrm{~min} ; 5.7 \mathrm{~kJ} \mathrm{~L}^{-1}\right)$. This occurs due to light absorption by $\mathrm{S}_{2} \mathrm{O}_{8}{ }^{2-}$ and thermal decomposition of this reagent leading to the formation of sulfate radicals (Ahmed and Chiron 2014).

Higher removal of LP compared to CBZ and CAF may be related to the chemical properties of this compound which contains the highest molar mass (330.739 $\mathrm{g} \mathrm{mol}^{-1}$ ) among all compounds along with a greater variety of reactive chemical structures for the attack of the sulfate radical, as shown in Table S1. LP removal within $1.2 \mathrm{~kJ} \mathrm{~L}^{-1}(15 \mathrm{~min})$ for all tested solar $/ \mathrm{Fe}^{2+} / \mathrm{S}_{2} \mathrm{O}_{8}{ }^{2-}$ conditions was similar to removals obtained after $5.7 \mathrm{~kJ} \mathrm{~L}^{-1}$ (60 min) (Fig. 1). This was not observed for CAF nor CBZ and is probably related to the higher molar absorption coefficient (Table S1) and quantum yield (Starling et al., 2019b) of this compound (Table S1), thus enabling faster degradation when submitted to irradiated processes. Meanwhile, CBZ (191.19 $\mathrm{g} \mathrm{mol}^{-1}$ ) and CAF (194.19) share very similar molar mass and chemical structures (Table S1), which explains their similar behavior when submitted to the solar photo-Fenton process. However, as the $\mathrm{pKa}$ of CBZ is lower (4.2) than that reported for CAF (10.4) (Carlson et al. 2015), CBZ is probably deprotonated at neutral $\mathrm{pH}$, which explains $40 \%$ removal in the presence of iron alone via complexation, as this reagent has positive charge. Expressive removal of CBZ by iron complexation was also observed in a previous study (Costa et al. 2019). Complexation with iron also occurred for $\mathrm{CAF}$, yet to a lower extent (20\% removal).

Considering all solar $/ \mathrm{Fe} / \mathrm{S}_{2} \mathrm{O}_{8}{ }^{2-}$ reactions performed at neutral $\mathrm{pH}$, assay \#4 conducted using $27.7 \mathrm{mg} \mathrm{L}^{-1}$ of $\mathrm{Fe}^{2+}$ aligned to the maximum concentration of $\mathrm{S}_{2} \mathrm{O}_{8}{ }^{2-}$ was the most favorable for the removal of the sum of CECs (Fig. S4). This assay (65\% removal of total CECs) was conducted using the intermittent iron addition strategy and was more efficient than assay \#6 (31\%) which was performed with similar reagent concentrations yet using a single iron addition. This suggests that the strategy to perform solar photoFenton at neutral $\mathrm{pH}$ using intermittent iron additions, previously proposed by Carra et al. (2014) for solar/Fe/ $\mathrm{H}_{2} \mathrm{O}_{2}$, is also effective when using persulfate as alternative oxidant in this process. Besides, repeated additions of iron in assay \#4 led to gradual oxidant consumption in this assay, reaching $54 \%$ by the end of the reaction. In contrast, $\mathrm{S}_{2} \mathrm{O}_{8}{ }^{2-}$ consumption was slower in the equivalent Fenton reaction reaching a maximum of $40 \%$. This indicates faster $\mathrm{Fe}^{2+}$ regeneration from $\mathrm{Fe}^{3+}$ under 
irradiation (Fig. S3 D), as expected for photo-Fenton systems and shown by Eq. 7.

$\mathrm{Fe}(\mathrm{OH})^{2+}+\mathrm{h}_{(540-580 \mathrm{~nm})} \rightarrow \mathrm{Fe}^{2+}+\mathrm{HO} \bullet$

Dissolved $\mathrm{Fe}^{2+}$ concentration was constantly below $1 \mathrm{mg} \mathrm{L}{ }^{-1}$ during assay \#5 $\left(27.8 \mathrm{mg} \mathrm{L}^{-1}\right.$ of $\mathrm{Fe}^{2+}$; $56.7 \mathrm{mg} \mathrm{L}^{-1}$ of $\mathrm{S}_{2} \mathrm{O}_{8}{ }^{2-}$ ) conducted with a single iron addition (Fig. S3C), as $\mathrm{S}_{2} \mathrm{O}_{8}{ }^{2-}$ was promptly consumed in the first five minutes of reaction. Meanwhile, in assay \#3 $\left(27.8 \mathrm{mg} \mathrm{L}^{-1}\right.$ of $\mathrm{Fe}^{2+} ; 56.7 \mathrm{mg} \mathrm{L}^{-1}$ of $\mathrm{S}_{2} \mathrm{O}_{8}{ }^{2-}$ ) conducted with intermittent iron additions, $\mathrm{Fe}^{2+}$ concentration was stable at nearly $5 \mathrm{mg} \mathrm{L}^{-1}$ (Fig. S3C), thus contributing to gradual $\mathrm{S}_{2} \mathrm{O}_{8}{ }^{2-}$ consumption throughout treatment. In assays \#4 (intermittent additions) and \#6 (single addition) which had maximum oxidant concentration $\left(282.2 \mathrm{mg} \mathrm{L}^{-1}\right)$, dissolved iron concentration was nearly $2.5 \mathrm{mg} \mathrm{L}^{-1}$ throughout the entire reaction (Fig. S3 D) due to higher availability of $\mathrm{S}_{2} \mathrm{O}_{8}{ }^{2-}$. As dissolved $\mathrm{Fe}^{2+}$ concentration was below $5 \mathrm{mg} \mathrm{L}^{-1}$ throughout all assays conducted at neutral $\mathrm{pH}$, there are no risks associated to dissolved iron concentration prior to MWWTP effluent reuse or discharge of treated effluent. Besides, as most of the catalyst added to the system precipitates by the end of the treatment, it may be easily removed.

Higher $\mathrm{S}_{2} \mathrm{O}_{8}{ }^{2-}$ consumption (54\%) and CEC removal (62\%) in assay \#4 (intermittent iron additions) compared to assay \#6 (single iron addition: $20 \%$ oxidant consumption; $35 \%$ removal of CECs) confirms the feasibility of using the proposed iron addition strategy for the operation of solar $/ \mathrm{Fe} /$ $\mathrm{S}_{2} \mathrm{O}_{8}{ }^{2-}$ at neutral $\mathrm{pH} . \mathrm{S}_{2} \mathrm{O}_{8}{ }^{2-}$ consumption in assay \#6 was limited due to high turbidity observed right after iron addition, thus limiting further reactions between $\mathrm{Fe}^{2+}$ and $\mathrm{S}_{2} \mathrm{O}_{8}{ }^{2-}$ and $\mathrm{Fe}^{2+}$ regeneration by light absorption (Eq. 7) (Freitas et al. 2017). Consequently, $\mathrm{S}_{2} \mathrm{O}_{8}{ }^{2-}$ was in excess in assay \#6 contributing to self-scavenger reactions and leading to radical consumption by $\mathrm{S}_{2} \mathrm{O}_{8}{ }^{2-}$ and to the regeneration of $\mathrm{S}_{2} \mathrm{O}_{8}{ }^{2-}$ as shown in Eqs. 8 and 9 (Kwon et al. 2015).

$$
\begin{aligned}
& \mathrm{SO}_{4}{ }^{-}+\mathrm{S}_{2} \mathrm{O}_{8}{ }^{2-} \rightarrow \mathrm{SO}_{4}{ }^{2-}+\mathrm{S}_{2} \mathrm{O}_{8}{ }^{-\bullet} \\
& \mathrm{SO}^{-\bullet}+\mathrm{SO}^{-}{ }^{-} \rightarrow \mathrm{S}_{2} \mathrm{O}_{8}{ }^{2-}
\end{aligned}
$$

Additionally, no $\mathrm{pH}$ decay was observed during solar $/ \mathrm{Fe} /$ $\mathrm{S}_{2} \mathrm{O}_{8}{ }^{2-}$ reactions performed at neutral $\mathrm{pH}$ (Fig. 1d). This may be considered an advantage as it is not necessary to adjust the $\mathrm{pH}$ prior to reuse or disposal, and there is possible coexistence of $\mathrm{SO}_{4}{ }^{--}$and $\mathrm{OH}^{-}$radicals at neutral $\mathrm{pH}$ as shown in Eqs. 10 and 11 (Wacławek et al. 2017).

$\mathrm{SO}_{4}{ }^{-\bullet}+\mathrm{H}_{2} \mathrm{O} \rightarrow \mathrm{HO}^{\bullet}+\mathrm{HSO}_{4}{ }^{-}$
$\mathrm{SO}_{4}{ }^{-}+\mathrm{OH}^{-} \rightarrow \mathrm{SO}_{4}{ }^{2-}+\mathrm{HO}^{\bullet}$

All solar $/ \mathrm{Fe} / \mathrm{S}_{2} \mathrm{O}_{8}{ }^{2-}$ conditions performed as reference experiments at acidic $\mathrm{pH}$ led to $>80 \%$ removal of all target
CECs (Fig. 1a-c). These results are more satisfactory than those achieved in other studies which also applied persulfate as an alternative oxidant in solar photo-Fenton reactions at acidic pH (Ahmed and Chiron 2014; Miralles-Cuevas et al. 2017), since $92 \%$ of all CECs were removed in assay \#7 using much lower concentrations of both reagents $\left(2.75 \mathrm{mg} \mathrm{L}^{-1}\right.$ of $\mathrm{Fe}^{2+} ; 57.6 \mathrm{mg} \mathrm{L}^{-1}$ of $\mathrm{S}_{2} \mathrm{O}_{8}{ }^{2}$ ) when compared to the concentration applied in referred studies. Besides, the optimum $\mathrm{Fe}: \mathrm{S}_{2} \mathrm{O}_{8}{ }^{2-}$ molar ratio obtained for the removal of CECs was 1:6, which is similar to that obtained in Wang et al. (2017), when treating sulfamethazine via UV-Vis $\mathrm{LED} / \mathrm{Fe}(\mathrm{II}) / \mathrm{S}_{2} \mathrm{O}_{8}{ }^{2-}$.

Still regarding experiments conducted at $\mathrm{pH} 3$, maximum removal of CECs and COD were obtained in assays \#9 (> $90 \%$ removal of CECs; $>99 \%$ removal of COD) and 10 (> $90 \%$ removal of CECs; > 99\% removal of COD), both with $27.7 \mathrm{mg} \mathrm{L}^{-1}$ of $\mathrm{Fe}^{2+}$ in the presence of minimum and maximum $\mathrm{S}_{2} \mathrm{O}_{8}{ }^{2-}$ concentrations, respectively (Fig. 1d). $\mathrm{S}_{2} \mathrm{O}_{8}{ }^{2-}$ consumption was nearly $85 \%$ in assay \#9, yet it was limited to $40 \%$ in assay \#10 (167 $\mathrm{mg} \mathrm{L}^{-1}$ of remaining $\left.\mathrm{S}_{2} \mathrm{O}_{8}{ }^{2-}\right)$, which had nearly five times the initial concentration of $\mathrm{S}_{2} \mathrm{O}_{8}{ }^{2-}$ present in assay \#9 (Fig. S3 A). pH decayed to values ranging between 2 and 2.8 during assays conducted as reference experiments at acidic $\mathrm{pH}$.

\section{Solar $/ \mathrm{Fe}^{2+} / \mathrm{H}_{2} \mathrm{O}_{2}$ and solar $/ \mathrm{Fe}^{2+} / \mathrm{S}_{2} \mathrm{O}_{8}{ }^{2-}$ at semi-pilot scale}

\section{Removal of CECs}

Figure 2a shows total removal of CECs, consumption of oxidants, and COD removal, during photo-Fenton treatments performed in semi-pilot scale at neutral $\mathrm{pH}$ using the intermittent iron addition strategy. Final removal of CECs obtained during solar $/ \mathrm{Fe} / \mathrm{H}_{2} \mathrm{O}_{2}$ at near-neutral $\mathrm{pH}$ reached $49 \%$, and removal efficiencies obtained for $\mathrm{CAF}, \mathrm{CBZ}$, and $\mathrm{LP}$ (Fig. 2a, c-e) were $49 \%, 45 \%$, and $52 \%$, respectively. In contrast, $55 \%$ removal of total CECs was obtained $(43 \% \mathrm{CAF}$, $59 \% \mathrm{CBZ}$, and $61 \% \mathrm{LP}$ ) via solar/Fe/ $\mathrm{S}_{2} \mathrm{O}_{8}{ }^{2-}$ (Fig. 2a, c-e). Removal rates are lower than those obtained by MirallesCuevas et al. (2017) and Ahmed and Chiron (2014), who reached more than $90 \%$ removal of a mixture of CECs and carbamazepine, respectively. This difference is related to the $\mathrm{pH}$ of reactions, as referred studies were conducted at acidic $\mathrm{pH}$.

$\mathrm{S}_{2} \mathrm{O}_{8}{ }^{2-}$ consumption was faster in the beginning of the reaction when compared to $\mathrm{H}_{2} \mathrm{O}_{2}$, showing a slower consumption after $15 \mathrm{~min}$ of reaction $\left(Q_{\mathrm{UV}}=0.5 \mathrm{~kJ} \mathrm{~L}^{-1}\right)$ (Fig. 2a). Meanwhile, $\mathrm{H}_{2} \mathrm{O}_{2}$ consumption increased along the reaction reaching a maximum of $75 \%\left(Q_{\mathrm{UV}}=2.5 \mathrm{~kJ} \mathrm{~L}^{-1}\right)$. Total decay of CECs followed a similar pattern to that observed for oxidant consumption in solar $/ \mathrm{Fe} / \mathrm{S}_{2} \mathrm{O}_{8}{ }^{2-}$, as it occurred very quickly in the beginning of the reaction and stabilized after $30 \min \left(Q_{\mathrm{UV}}=1 \mathrm{~kJ} \mathrm{~L}^{-1}\right)$. In contrast, removal of CECs 
occurred only until $25 \mathrm{~min}$ of reactions $\left(Q_{\mathrm{UV}}=1.25 \mathrm{~kJ} \mathrm{~L}^{-1}\right)$ in the solar $/ \mathrm{Fe} / \mathrm{H}_{2} \mathrm{O}_{2}$, yet $\mathrm{H}_{2} \mathrm{O}_{2}$ consumption continued to occur. This indicates higher selectivity of sulfate radicals towards CECs when compared to hydroxyl radicals. As COD decreased continuously in both treatments, these oxidants are also being consumed by matrix components present in a higher concentration than target CECs in the matrix. CEC removal and COD decay, aligned to oxidant consumption profiles are shown in Fig. 2a, and reveal that oxidant consumption by matrix components is more significant for $\mathrm{H}_{2} \mathrm{O}_{2}$, thus confirming the advantages of using persulfate as an alternative oxidant in the photo-Fenton process for the treatment of real matrices as it is less reactive towards matrix components.

Considering that the same molar concentration of each oxidant was used in both systems, yet lower accumulated irradiation was required for proper removal of CECs during solar/ $\mathrm{Fe} / \mathrm{S}_{2} \mathrm{O}_{8}{ }^{2-}$, this process was more effective for the removal of CECs from real MWWTP effluent at neutral $\mathrm{pH}$ when compared to solar $/ \mathrm{Fe} / \mathrm{H}_{2} \mathrm{O}_{2}$. Carra et al. (2013) observed $\mathrm{pH}$ decay after every iron addition due to the hydrolysis of $\mathrm{Fe}^{2+}$, when applying solar $/ \mathrm{Fe} / \mathrm{H}_{2} \mathrm{O}_{2}$ at neutral $\mathrm{pH}$ using intermittent iron additions. As shown in Fig. 2b, no pH decay was observed during reactions performed in this study due to matrix buffer effect, confirming results obtained at laboratory scale.
Solar $/ \mathrm{Fe} / \mathrm{S}_{2} \mathrm{O}_{8}{ }^{2-}$ also showed faster removal of each CEC individually. While $43 \%$ of CAF removal were achieved within $30 \min \left(Q_{\mathrm{UV}}=0.9 \mathrm{~kJ} \mathrm{~L}^{-1}\right)$, this same efficiency was only achieved after $40 \mathrm{~min}\left(Q_{\mathrm{UV}}=1.5 \mathrm{~kJ} \mathrm{~L}{ }^{-1}\right)$ via solar $/ \mathrm{Fe} / \mathrm{H}_{2} \mathrm{O}_{2}$ (Fig. 2c). Additionally, final CAF removal via solar/Fe/ $/ \mathrm{H}_{2} \mathrm{O}_{2}$ (49\%) was superior to that $(20 \%)$ reached by Klamerth et al. (2010) under solar irradiation, as he used lower $\mathrm{Fe}^{2+}$ concentration.

Among all target compounds, LP was the most sensitive in terms of reaction rate, showing $50 \%$ decay within $5 \mathrm{~min}$ $\left(Q_{\mathrm{UV}}=0.06 \mathrm{~kJ} \mathrm{~L}^{-1}\right)$ when persulfate was used as an oxidant (Fig. 2e). LP removal during this treatment stabilized at nearly $60 \%$, while maximum removal using $\mathrm{H}_{2} \mathrm{O}_{2}$ as an oxidant was $52 \%$ ( $35 \mathrm{~min}, Q_{\mathrm{UV}}=1.3 \mathrm{~kJ} \mathrm{~L}^{-1}$ ), therefore indicating higher reactivity of LP to sulfate radical-based AOPs when compared to hydroxyl radical, as also observed under UV-C irradiation (Starling et al., 2019a). A higher molar absorption coefficient associated to LP when compared to CAF and CBZ (Table S1) probably led to faster removal of this target compound, as also observed in laboratory scale.

With regard to CBZ (Fig. 2d), while $30 \mathrm{~min}\left(Q_{\mathrm{UV}}=\right.$ $1 \mathrm{~kJ} \mathrm{~L}^{-1}$ ) was necessary to remove $50 \%$ of $\mathrm{CBZ}$ via solar/ $\mathrm{Fe} / \mathrm{S}_{2} \mathrm{O}_{8}{ }^{2-}$, the same removal was only achieved after $45 \mathrm{~min}\left(Q_{\mathrm{UV}}=2 \mathrm{~kJ} \mathrm{~L}^{-1}\right)$ under solar $/ \mathrm{Fe} / \mathrm{H}_{2} \mathrm{O}_{2}$ at neutral $\mathrm{pH}$. Interestingly, both processes showed the same degradation
Fig. 2 a COD ( $\square$ scatter), total emerging contaminant (CECs) decay ( $\hbar_{5}$ scatter), and reagent consumption (-ם-scatter + line), and $\mathbf{b} \mathrm{pH}$ and temperature monitored during solar $/ \mathrm{Fe} / \mathrm{H}_{2} \mathrm{O}_{2}$ (filled symbols) and solar $/ \mathrm{Fe} / \mathrm{S}_{2} \mathrm{O}_{8}{ }^{2}$ - (empty symbols) conducted at neutral $\mathrm{pH}$ in a semi-pilot scale RPR, as well as $\mathbf{c}$ caffeine, $\mathbf{d}$ carbendazim, and e losartan potassium decay during treatments

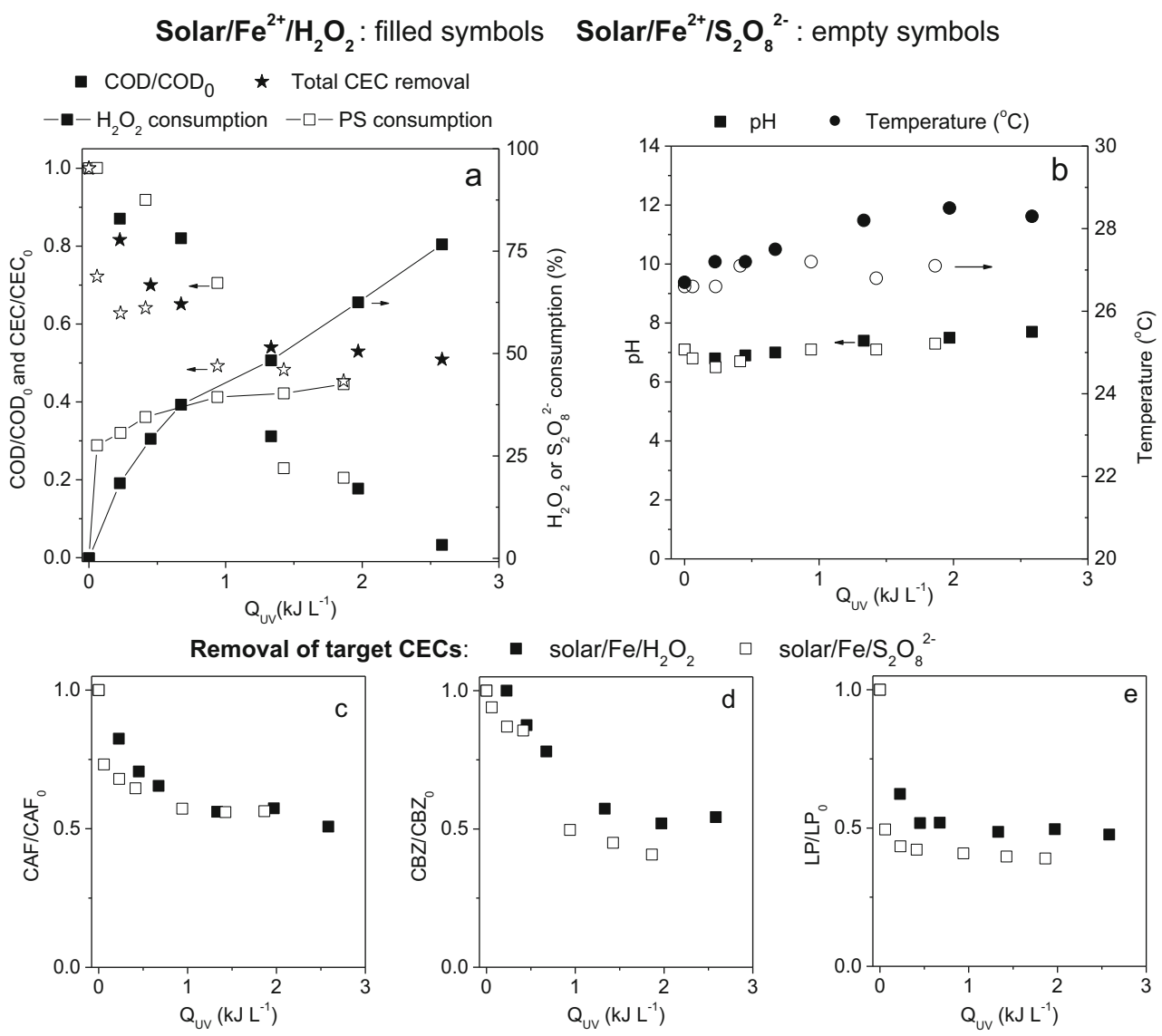


profile, with slow removal before 15 min of treatment followed by a fast decay after all iron additions. This confirms the effect of iron complexation towards CBZ removal as shown by control experiments performed in laboratory scale (Fig. 1b).

\section{Impact of treatments on acute toxicity and disinfection}

Acute toxicity assays performed with samples withdrawn during solar $/ \mathrm{Fe} / \mathrm{H}_{2} \mathrm{O}_{2}$ and solar/ $/ \mathrm{Fe} / \mathrm{S}_{2} \mathrm{O}_{8}{ }^{2-}$ at neutral $\mathrm{pH}$ in the RPR reactor showed that MWWTP effluent was not toxic towards luminescent bacteria (a.T.u. $=0.6$ ) before treatment, and that none of the processes generated toxicity since all values were below 1.21 a.T.u. (line) (Fig. 3a, b) as previously reported elsewhere (Esteban García et al. 2018; Freitas et al. 2017). These results suggest that it would be appropriate to apply any of these processes prior to the disposal of treated effluent.

Bernabeu et al. (2012) investigated acute toxicity of a mixture of CECs (initial concentration $=5 \mathrm{mg} \mathrm{L}^{-1}$ ), including CAF, present in MWWTP effluent upon Allivibrio fischeri, before and after treatment, and found an increase in acute toxicity in the beginning of treatment, followed by proper removal after solar $/ \mathrm{Fe} / \mathrm{H}_{2} \mathrm{O}_{2}$ at neutral $\mathrm{pH}$. This was confirmed by Freitas et al. (2017) who obtained no toxicity for MWWTP effluent containing CECs neither before nor
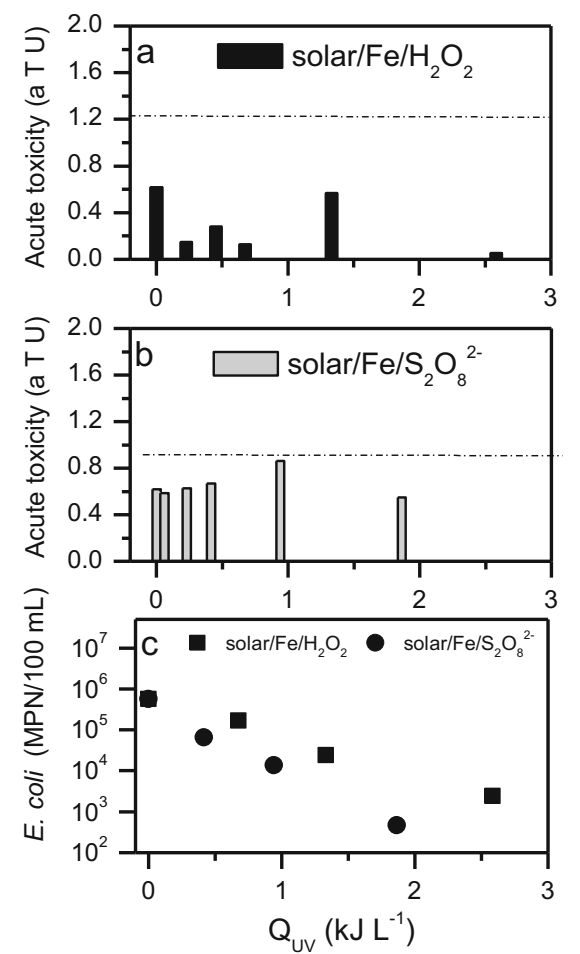

Fig. 3 Acute toxicity values obtained for samples withdrawn during a solar $/ \mathrm{Fe} / \mathrm{H}_{2} \mathrm{O}_{2}$ and $\mathbf{b}$ solar $/ \mathrm{Fe} / \mathrm{S}_{2} \mathrm{O}_{8}{ }^{2-}$ assays conducted at neutral $\mathrm{pH}$ in a raceway pond reactor (values above the dashed line are toxic) and $\mathbf{c}$ E. coli decay during solar $/ \mathrm{Fe} / \mathrm{H}_{2} \mathrm{O}_{2}$ and solar $/ \mathrm{Fe} / \mathrm{S}_{2} \mathrm{O}_{8}{ }^{2-}$ in the same experiment after treatment by solar $/ \mathrm{Fe} / \mathrm{H}_{2} \mathrm{O}_{2}$ at neutral $\mathrm{pH}$. However, to this date, there are no studies reporting the evolution of acute toxicity during solar $/ \mathrm{Fe} / \mathrm{S}_{2} \mathrm{O}_{8}{ }^{2-}$ treatment of real MWWTP effluent at neutral $\mathrm{pH}$.

When it comes to wastewater reuse, disinfection is a critical endpoint. As observed in Fig. 3c, solar/ $/ \mathrm{Fe} / \mathrm{S}_{2} \mathrm{O}_{8}{ }^{2-}$ was more effective on the removal of $E$. coli $\left(3 \log\right.$ units; $Q_{\mathrm{UV}}=$ $\left.1.9 \mathrm{~kJ} \mathrm{~L}^{-1}\right)$ than solar $/ \mathrm{Fe} / \mathrm{H}_{2} \mathrm{O}_{2}\left(2.5 \log\right.$ units; $Q_{\mathrm{UV}}=$ $2.5 \mathrm{~kJ} \mathrm{~L}^{-1}$ ). Results obtained by Esteban García et al. (2018) for $E$. coli removal via solar/ $/ \mathrm{Fe} / \mathrm{H}_{2} \mathrm{O}_{2}$ were similar to those observed here for solar $/ \mathrm{Fe} / \mathrm{S}_{2} \mathrm{O}_{8}{ }^{2-}$. Although it is still necessary to investigate mechanisms of cell damage via sulfate radical-based oxidation processes, it is known that external and internal cell photo-Fenton reactions occur via oxidation by hydroxyl radicals (Feng et al. 2020; Xiao et al. 2019).

\section{Inactivation of ARB}

Figure 4 reveals that the removal of strains resistant to ampicillin (AMO), chloramphenicol (CLO), erythromycin (ERY), amoxicillin (AMO), sulfadiazine (INE), sulfamethoxazole (AZOLE), and to the combination of trimethoprim and sulfamethoxazole (TRI + AZOLE) was higher via solar $/ \mathrm{Fe} / \mathrm{S}_{2} \mathrm{O}_{8}{ }^{2-}$ compared to solar $/ \mathrm{Fe} / \mathrm{H}_{2} \mathrm{O}_{2}$, reaching a maximum of $3 \mathrm{log}$ units for bacteria resistant to AMP and AMO. In another study, $6 \log$ decay of carbapenem-resistant bacteria in real hospital wastewater was achieved within $50 \mathrm{~min}$ via solar/ $\mathrm{Fe} / \mathrm{S}_{2} \mathrm{O}_{8}{ }^{2-}$ at neutral $\mathrm{pH}$ using citric acid as a complexing

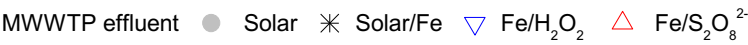
$\star$ solar $/ \mathrm{Fe} / \mathrm{H}_{2} \mathrm{O}_{2} \star$ solar $/ \mathrm{Fe} / \mathrm{S}_{2} \mathrm{O}_{8}^{2-}$

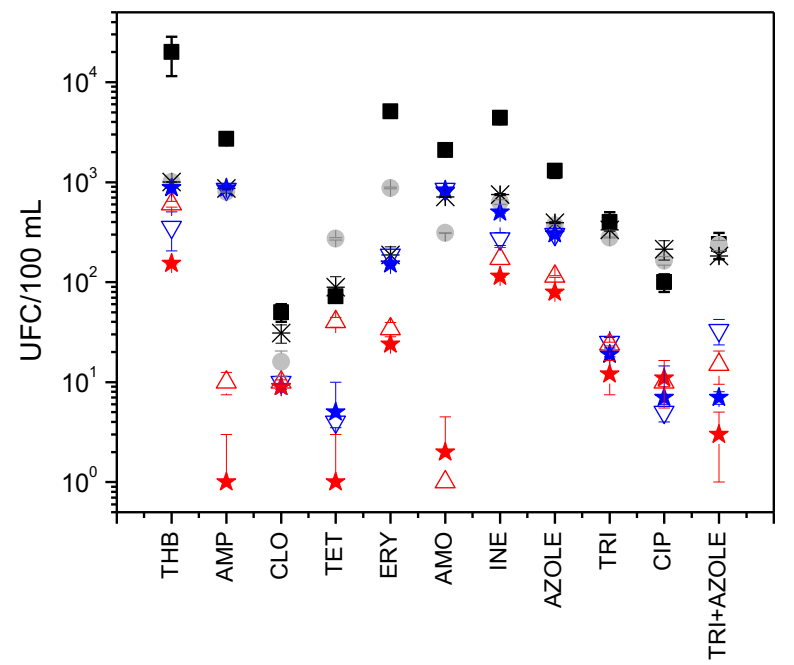

Fig. 4 Inactivation of ARB after solar/ $/ \mathrm{Fe} / \mathrm{S}_{2} \mathrm{O}_{8}{ }^{2-}$ and solar $/ \mathrm{Fe} / \mathrm{H}_{2} \mathrm{O}_{2}$ compared to non-treated MWWTP secondary effluent. (THB, total heterotrophic bacteria; AMP, ampicillin; CLO, chloramphenicol; TET, tetracycline; ERY, erythromycin; AMO, amoxicillin; INE, sulfadiazine; AZOLE, sulfamethoxazole; TRI, trimethoprim; AZOLE + TRI, sulfamethoxazole + trimethoprim) 
agent when compared to $3.5 \log$ within $300 \mathrm{~min}$ via solar $/ \mathrm{Fe} /$ $\mathrm{H}_{2} \mathrm{O}_{2}$ (Serna-Galvis et al. 2019b).

Overall, disinfection mechanisms during photo-Fenton processes occur via extra- and intracellular mechanisms. The exposition to UV-A alone leads to increased cell permeability due to stress and induces the formation of reactive oxygen species (ROS), thus culminating in internal photo-Fenton mechanisms which lead to accumulated cell damage followed by death. The period in which ARB accumulate damage was recently nominated as lag period (Serna-Galvis et al. 2019a). Besides the combined detrimental effect of UV light and heat, solar irradiation alone induces a sequence of oxidative outcomes inside cells described as the internal photo-Fenton. Internal photo-Fenton is driven by the loss of $\mathrm{Fe}^{2+}$ from enzymes and clusters that contain $\mathrm{Fe}$, leading to intracellular damage with loss of protein function followed by death (Giannakis et al. 2017). The addition of oxidant and iron salts to the matrix accelerates the natural process by enhancing internal and launching external photo-Fenton reactions. Moreover, the UV-B component in solar irradiation is confirmed to have a direct damaging effect upon DNA (Feng et al. 2020). Although pathways of inactivation of biomoleculescarbohydrates, lipids, proteins, and DNA—via $\mathrm{OH}^{*}$ have been intensely discussed in the literature, reaction mechanisms between $\mathrm{SO}_{4}{ }^{-}$and these molecules are not yet fully elucidated (Xiao et al. 2019). A recent study suggests that higher inactivation of ARB via sulfate radical-based AOPs may be related to the coexistence of $\mathrm{OH} \cdot$ and $\mathrm{SO}_{4}{ }^{--}$radicals in the system at neutral pH (Xiao et al. 2019).

As shown in Fig. 4, removal of total and resistant bacteria via solar disinfection (sun only) was limited to a maximum of one log unit, and solar/ $/ \mathrm{Fe} / \mathrm{S}_{2} \mathrm{O}_{8}{ }^{2-}$ was 2 to $3 \log$ units more efficient than solar disinfection for both THB and ARB. These results confirm the advantage of solar $/ \mathrm{Fe} / \mathrm{S}_{2} \mathrm{O}_{8}{ }^{2-}$ when compared to solar disinfection alone for the removal of ARB. Although some studies reveal that ARB relative abundance increases during solar photo-Fenton treatment, it may not be necessary to evaluate the ARB inactivation rate as a particular indicator, since it takes longer to remove pathogen indicators as the former are present in higher concentrations in real wastewater when compared to ARB (Fiorentino et al. 2019). Also, solar $/ \mathrm{Fe} / \mathrm{S}_{2} \mathrm{O}_{8}{ }^{2-}$ was similarly effective for total and resistant bacteria (Fig. 4), as it has been reported for solar/ $\mathrm{Fe} / \mathrm{H}_{2} \mathrm{O}_{2}$ (De la Obra et al. 2019; Giannakis et al. 2018).

Control experiment with $\mathrm{Fe} / \mathrm{S}_{2} \mathrm{O}_{8}{ }^{2-}$ showed similar efficiency to that of solar $/ \mathrm{Fe} / \mathrm{S}_{2} \mathrm{O}_{8}{ }^{2-}$ for the inactivation of bacteria resistant to ERY, INE, AZOLE, TRI, and CIP, thus confirming the Fenton-like effect on the inactivation of ARB (Fig. 4). This may be an advantage when considering continuous treatment operation in the MWWTP overnight, which was more efficient than operation in batch mode for the removal of bacteria resistant to cephalosporin via solar $/ \mathrm{Fe} / \mathrm{H}_{2} \mathrm{O}_{2}$ at neutral pH (De la Obra et al. 2019). In addition, $\mathrm{Fe} / \mathrm{S}_{2} \mathrm{O}_{8}{ }^{2-}$ was more effective than solar $/ \mathrm{Fe} / \mathrm{H}_{2} \mathrm{O}_{2}$ for the inactivation of bacteria resistant to AMP, ERY, AMO, INE, and AZOLE and TRI + AZOLE confirming higher efficiency of sulfate radical-based AOPs when compared to hydroxyl radicalbased AOP on the inactivation of pathogens (Wordofa et al. 2017).

It is worthy to note that treatment effectiveness varied among ARBs to the different antibiotics analyzed in this study (Fiorentino et al. 2019) which is probably related to phenotype differences and intrinsic resistance mechanisms pertaining to each strain (Rodríguez-Chueca et al. 2019b; Sharma et al. 2016). Previous studies have indicated the potential of $\mathrm{Fe} /$ $\mathrm{S}_{2} \mathrm{O}_{8}{ }^{2-}$ (Ahn et al. 2013) and solar/ $/ \mathrm{Fe} / \mathrm{S}_{2} \mathrm{O}_{8}{ }^{2-}$ on water disinfection (Rodríguez-Chueca et al. 2019a). Here, we call attention to the potential of the solar/ $/ \mathrm{Fe} / \mathrm{S}_{2} \mathrm{O}_{8}{ }^{2-}$ process at neutral $\mathrm{pH}$ on the disinfection and removal of ARB from MWWTP effluent prior to reuse or discharge.

\section{Cost-benefit analysis}

Table 2 shows the reactor surface area required for each of the proposed treatments. The solar photo-Fenton-like process using persulfate as an oxidant required $0.9 \mathrm{~kJ} \mathrm{~L}^{-1}$ of accumulated irradiation to reach $50 \%$ removal of $\mathrm{CEC}$ in neutral $\mathrm{pH}$, while the traditional solar photo-Fenton reached the same removal rate after $1.9 \mathrm{~kJ} \mathrm{~L}^{-1}$ of accumulated irradiation. Hence, the surface area required for the solar $/ \mathrm{Fe} / \mathrm{S}_{2} \mathrm{O}_{8}{ }^{2-}$ process was nearly two times lower than that required for the traditional solar photo-Fenton process.

Miralles-Cuevas et al. (2017) obtained surface area values equivalent to $3300 \mathrm{~m}^{2}$ for the traditional solar photo-Fenton process and $3200 \mathrm{~m}^{2}$ for the solar $/ \mathrm{Fe} / \mathrm{S}_{2} \mathrm{O}_{8}{ }^{2-}$ treatment in a CPC-type reactor at acidic $\mathrm{pH}$. Thus, surface area calculated here for the solar $/ \mathrm{Fe} / \mathrm{S}_{2} \mathrm{O}_{8}{ }^{2-}$ treatment is lower than that obtained in the reference study due to lower average local global incident irradiation in Almeria, Spain $\left(\mathrm{UV}_{\mathrm{G}}=18.6 \mathrm{~W} \mathrm{~m}^{-2}\right)$ when compared to the average incident irradiation in Belo Horizonte $\left(\mathrm{UV}_{\mathrm{G}}=30 \mathrm{~W} \mathrm{~m}^{-2}\right)$, confirming the high potential of using solar irradiation in tropical locations (Marcelino et al. 2014; Esteban García et al. 2018).

Investment and amortization costs were calculated according to reactor surface area (Table 2). Since the required surface area was lower for solar $/ \mathrm{Fe} / \mathrm{S}_{2} \mathrm{O}_{8}{ }^{2-}$, the investment cost related to this process was also lower than that obtained for solar/ $\mathrm{Fe} / \mathrm{H}_{2} \mathrm{O}_{2}$. As a consequence, the amortization cost related to the solar/ $/ \mathrm{Fe} / \mathrm{S}_{2} \mathrm{O}_{8}{ }^{2-}$ is nearly half the cost related to the system using $\mathrm{H}_{2} \mathrm{O}_{2}$. In contrast, amortization costs obtained by Miralles-Cuevas et al. (2017) were slightly lower than the ones obtained here. This is related to the interest rate in each country. If the $6 \%$ interest rate applicable to Spain was to be applied in this study, AC would drop to 0.9 and $0.4 € \mathrm{~m}^{-3}$ for the traditional and solar photo-Fenton-like treatments, respectively. 
Table 2 Surface area $\left(S_{\mathrm{S}}\right)$, investment costs (IC), amortization costs (AC), operating costs (OC), and total costs associated to solar/ $/ \mathrm{Fe} / \mathrm{S}_{2} \mathrm{O}_{8}{ }^{2-}$ and solar photo-Fenton and solar/ $/ \mathrm{Fe} / \mathrm{H}_{2} \mathrm{O}_{2}$ at neutral $\mathrm{pH}$ using intermittent iron additions as according to results obtained in semi-pilot scale

\begin{tabular}{|c|c|c|c|}
\hline Variable & Unit & $\begin{array}{l}\mathrm{Solar} / \mathrm{Fe} / \\
\mathrm{H}_{2} \mathrm{O}_{2}\end{array}$ & $\begin{array}{l}\mathrm{Solar} / \mathrm{Fe} / \\
\mathrm{S}_{2} \mathrm{O}_{8}{ }^{2-}\end{array}$ \\
\hline \multicolumn{4}{|c|}{ Solar photo-reactor surface area $\left(S_{\mathrm{S}}\right)$} \\
\hline$Q_{\mathrm{UVG}}$ & $\mathrm{kJ} \mathrm{L}^{-1}$ & 1.9 & 0.9 \\
\hline$V_{\mathrm{t}}$ & $\mathrm{L}$ & 365,000 & 365,000 \\
\hline$H_{\mathrm{s}}$ & $\mathrm{h}$ & 4380 & 4380 \\
\hline $\mathrm{UV}_{\mathrm{G}}$ & $\mathrm{W} \mathrm{m}^{-2}$ & 30 & 30 \\
\hline Surface area & $\mathrm{m}^{2}$ & 4750 & 2250 \\
\hline \multicolumn{4}{|c|}{ Investment costs (IC) } \\
\hline $\mathrm{Cb}$ & $€$ & 12,090 & 12,090 \\
\hline $\mathrm{Sb}$ & $\mathrm{m}^{2}$ & 4750 & 2250 \\
\hline $\mathrm{Sb}$ & $\mathrm{m}^{2}$ & 1000 & 1000 \\
\hline Total IC & $€$ & $57,427.50$ & $27,202.50$ \\
\hline \multicolumn{4}{|c|}{ Amortization cost (AC) } \\
\hline IC & $€$ & $57,427.50$ & $27,202.50$ \\
\hline Interest rate $(\%)$ & $\mathrm{m}^{2}$ & 7.5 & 7.5 \\
\hline Period & year & 20 & 20 \\
\hline Total IC & $€$ year $^{-1}$ & $430,706.25$ & $204,018.75$ \\
\hline \multicolumn{4}{|c|}{ Operating costs (OC) } \\
\hline $\mathrm{H}_{2} \mathrm{O}_{2} 33 \%(\mathrm{v} / \mathrm{v})$ & $€$ day $^{-1}$ & 68.63 & none \\
\hline $\mathrm{Na}_{2} \mathrm{SO}_{8}$ & & None & 3329.96 \\
\hline $\mathrm{FeSO}_{4} \cdot 7 \mathrm{H}_{2} \mathrm{O}$ & & 39.05 & 39.05 \\
\hline $\mathrm{H}_{2} \mathrm{SO}_{4}$ & & 4.17 & 4.17 \\
\hline $\mathrm{NaOH}$ & & None & None \\
\hline Total OC & $€$ day $^{-1}$ & 111.84 & 3373.18 \\
\hline \multicolumn{4}{|l|}{ Total cost (TC) } \\
\hline $\mathrm{AC}$ & $€$ year $^{-1}$ & $430,706.25$ & $204,018.75$ \\
\hline $\mathrm{OC}$ & $€$ day $^{-1}$ & 111.84 & 3373.18 \\
\hline $\mathrm{Vt}$ & $\mathrm{m}^{3}$ & 365,000 & 365,000 \\
\hline $\mathrm{TC}$ & $€ \mathrm{~m}^{-3}$ & 1.18 & 0.57 \\
\hline
\end{tabular}

Operational costs were calculated for both solar photoFenton treatments considering the use of $55 \mathrm{mg} \mathrm{L}^{-1}$ of $\mathrm{Fe}$ $(1 \mathrm{mM})$ and $50 \mathrm{mg} \mathrm{L}^{-1}$ of $\mathrm{H}_{2} \mathrm{O}_{2}(1.47 \mathrm{mM})$ or $282.2 \mathrm{mg} \mathrm{L}^{-1}$ of $\mathrm{S}_{2} \mathrm{O}_{8}{ }^{2-}(1.47 \mathrm{mM})$. Therefore, the volume of acid used to adjust the $\mathrm{pH}$ to 7 was also considered as an operational cost for both treatments. Operational costs were higher for the solar $/ \mathrm{Fe} / \mathrm{S}_{2} \mathrm{O}_{8}{ }^{2-}$ when compared to solar $/ \mathrm{Fe} / \mathrm{H}_{2} \mathrm{O}_{2}$ (Table 2) due to the cost of sodium persulfate which is 26 times more expensive than hydrogen peroxide (Table S3).

Although operational costs related to the application of solar/ $/ \mathrm{Fe} / \mathrm{S}_{2} \mathrm{O}_{8}{ }^{2-}$ at neutral $\mathrm{pH}$ are increased due to high prices associated to sodium persulfate, the lower surface area required for this process pushed the total cost of the operation to a lower price than that observed for solar $/ \mathrm{Fe} / \mathrm{H}_{2} \mathrm{O}_{2}$ (Table 2). The TC of solar/Fe/ $/ \mathrm{S}_{2} \mathrm{O}_{8}{ }^{2-}$ at near-neutral $\mathrm{pH}$ in this study is lower than the cost estimated by Miralles-
Cuevas et al. (2017) $\left(0.72 € \mathrm{~m}^{-3}\right)$ who conducted this treatment at acidic $\mathrm{pH}$, yet in a more expensive reactor.

Finally, total costs obtained in this study for each of the proposed treatments are competitive when compared to other advanced technologies used for the treatment of CEC in MWWTP effluent. A total cost of 1.1-1.9 $€ \mathrm{~m}^{-3}$, for example, was estimated for the treatment of wastewater containing a mix of pesticides by combined photo-Fenton/membrane bioreactor. Other technologies such as adsorption and reverse osmosis alone may cost from 0.07 to $90 \mathrm{USD} \mathrm{mg}^{-1}$ of pollutant and lead to the generation of a solid waste or concentrated solution, respectively, which must be disposed of or treated afterwards (Adeleye et al. 2016). In addition, UV-C-based processes are usually associated to higher operational prices as electric energy is required with costs varying from 0.4 to $1.4 € \mathrm{~m}^{-3}$ depending on the volume of wastewater treated (Roccaro et al. 2013).

\section{Conclusions}

Solar $/ \mathrm{Fe} / \mathrm{S}_{2} \mathrm{O}_{8}{ }^{2-}$ performed at laboratory scale using total $\mathrm{Fe}^{2+}$ concentration equivalent to $27.7 \mathrm{mg} \mathrm{L}^{-1}$ at neutral $\mathrm{pH}$ achieved up to $60 \%$ removal of total CECs with no $\mathrm{pH}$ decay. The treatment using intermittent iron additions was more effective for the removal of CECs than that using a single addition, thus confirming, for the first time, the effectiveness of this strategy using persulfate as an oxidant at neutral $\mathrm{pH}$. Dissolved $\mathrm{Fe}^{2+}$ and $\mathrm{S}_{2} \mathrm{O}_{8}{ }^{2-}$ consumption profiles showed that dissolved $\mathrm{Fe}^{2+}$ concentration was lower than $5 \mathrm{mg} \mathrm{L}^{-1}$ during the entire reaction, confirming the safe discharge of this treated effluent.

Solar $/ \mathrm{Fe} / \mathrm{H}_{2} \mathrm{O}_{2}$ and solar $/ \mathrm{Fe} / \mathrm{S}_{2} \mathrm{O}_{8}{ }^{2-}$ conducted at neutral $\mathrm{pH}$ in a raceway pond reactor led to a maximum of $49 \%$ $\left(Q_{\mathrm{UV}}=2.5 \mathrm{~kJ} \mathrm{~L}^{-1}\right)$ and $54 \%\left(Q_{\mathrm{UV}}=1.9 \mathrm{~kJ} \mathrm{~L}^{-1}\right)$ removal of total CECs, respectively. Therefore, solar/ $\mathrm{Fe} / \mathrm{S}_{2} \mathrm{O}_{8}{ }^{2-}$ was more effective on the removal of the sum of CECs in real MWWTP effluent reaching a higher removal rate under lower accumulated irradiation $\left(Q_{\mathrm{UV}}\right)$. This may be associated to higher selectivity of oxidative radicals formed in the presence of sulfate as an oxidant towards CECs rather than matrix components during the solar photo-Fenton treatment.

In addition, solar $/ \mathrm{Fe} / \mathrm{S}_{2} \mathrm{O}_{8}{ }^{2-}$ was also more effective on the disinfection of MWWTP effluent, removing $3 \mathrm{log}$ units of E. coli and ARB, demonstrating the potential of using this treatment prior to MWWTP effluent reuse. As the proposed treatment did not generate acute toxicity upon Allivibrio fischeri, it may also be used safely as tertiary treatment prior to discharge. Besides, cost-benefit analysis indicated competitive costs of the proposed solar $/ \mathrm{Fe} / \mathrm{S}_{2} \mathrm{O}_{8}{ }^{2-}$ when compared to solar $/ \mathrm{Fe} / \mathrm{H}_{2} \mathrm{O}_{2}$ and other technologies which are usually applied as advanced treatment for the improvement of MWWTP effluent quality. 
Supplementary Information The online version contains supplementary material available at https://doi.org/10.1007/s11356-020-11802-z.

Acknowledgments The authors would like to thank the Foundation of Support and Research of the state of Minas Gerais (FAPEMIG), the Coordination of Superior Level Staff Improvement (CAPES), the National Council for Scientific and Technological Development $(\mathrm{CNPq})$, and the Bill and Melinda Gates Foundation (Grand Challenges Exploitations - Brazil, Process \# 443776/2018-0) for their support during this research

Authors' contributions Study conception and design-M. C. V. M. Starling and C. C. Amorim; experiment execution-M. C. V. M. Starling, E. P Costa, and F. A Souza; bioassay execution-M. C. V. M. Starling, E. C. Machado, and J. C Araújo. All of the authors contributed to the interpretation of the results and manuscript writing and revision. All of the authors read and approved the final manuscript.

Funding This work was supported by the Foundation of Support and Research of the state of Minas Gerais (FAPEMIG), the Coordination of Superior Level Staff Improvement (CAPES), the National Council for Scientific and Technological Development (CNPq), and the Bill and Melinda Gates Foundation (Grand Challenges Exploitations - Brazil, Process \# 443776/2018-0). The funding sources were not involved in study design, nor the collection, analysis, and interpretation of data, nor in the writing of the report, nor in the decision to submit the article for publication.

\section{Compliance with ethical standards}

Conflict of interest The authors declare that they have no conflict of interest.

Ethical approval Not applicable

Consent to participate Not applicable

Consent to publish Not applicable

Open Access This article is licensed under a Creative Commons Attribution 4.0 International License, which permits use, sharing, adaptation, distribution and reproduction in any medium or format, as long as you give appropriate credit to the original author(s) and the source, provide a link to the Creative Commons licence, and indicate if changes were made. The images or other third party material in this article are included in the article's Creative Commons licence, unless indicated otherwise in a credit line to the material. If material is not included in the article's Creative Commons licence and your intended use is not permitted by statutory regulation or exceeds the permitted use, you will need to obtain permission directly from the copyright holder. To view a copy of this licence, visit http://creativecommons.org/licenses/by/4.0/.

\section{References}

Adeleye AS, Conway JR, Garner K, Huang Y, Su Y, Keller AA (2016) Engineered nanomaterials for water treatment and remediation: costs, benefits, and applicability. Chem Eng J 286:640-662. https://doi.org/10.1016/j.cej.2015.10.105

Ahmed MM, Brienza M, Goetz V, Chiron S (2014) Solar photo-Fenton using peroxymonosulfate for organic micropollutants removal from domestic wastewater: comparison with heterogeneous $\mathrm{TiO} 2$ photocatalysis. Chemosphere 117:252-256. https://doi.org/10. 1016/j.chemosphere.2014.07.046

Ahmed MM, Chiron S (2014) Solar photo-Fenton like using persulphate for carbamazepine removal from domestic wastewater. Water Res 48:229-236. https://doi.org/10.1016/j.watres.2013.09.033

Ahn S, Peterson TD, Righter J, Miles DM, Tratnyek PG (2013) Disinfection of ballast water with iron activated persulfate. Environ Sci Technol 47:11717-11725. https://doi.org/10.1021/ es $402508 \mathrm{k}$

APHA (2012) Standard methods for the examination of water and wastewater. Washington

Barceló D (2008) Aguas continentales: Gestión de recursos hídricos, tratamiento y calidad del agua. CSIC

Bernabeu A, Palacios S, Vicente R, Vercher RF, Malato S, Arques A, Amat AM (2012) Solar photo-Fenton at mild conditions to treat a mixture of six emerging pollutants. Chem Eng J 198-199:65-72. https://doi.org/10.1016/j.cej.2012.05.056

BRASIL (2017) Interest drops to $7.5 \%$ per year, the lowest rate since April 2013. http://www.brasil.gov.br/economia-e-emprego/2017/ 10/juros-caem-para-7-5-ao-ano-menor-taxa-desde-abril-de-2013. Accessed January 1st 2018 (in Portuguese)

Brooks JP, Maxwell SL, Rensing C, Gerba CP, Pepper IL (2007) Occurrence of antibiotic-resistant bacteria and endotoxin associated with the land application of biosolids. Can J Microbiol 53:616-622. https://doi.org/10.1139/W07-021

Carlson JC, Stefan MI, Parnis JM, Metcalfe CD (2015) Direct UV photolysis of selected pharmaceuticals, personal care products and endocrine disruptors in aqueous solution. Water Res 84:350-361. https://doi.org/10.1016/j.watres.2015.04.013

Carra I, Casas López JL, Santos-Juanes L, Malato S, Sánchez Pérez JA (2013) Iron dosage as a strategy to operate the photo-Fenton process at initial neutral pH. Chem Eng J 224:67-74. https://doi.org/10. 1016/j.cej.2012.09.065

Carra I, Santos-Juanes L, Fernández FG, Malato S, Sánchez Pérez JA (2014) New approach to solar photo-Fenton operation. Raceway ponds as tertiary treatment technology. J Hazard Mater 279:322329. https://doi.org/10.1016/j.jhazmat.2014.07.010

Clarizia L, Russo D, Di Somma I, Marotta R, Andreozzi R (2017) Homogeneous photo-Fenton processes at near neutral $\mathrm{pH}$ : a review. Appl Catal B Environ 209:358-371. https://doi.org/10.1016/j. apcatb.2017.03.011

Costa EP, Bottrel SEC, Starling MCVM, Leão MMD, Amorim CC (2019) Degradation of carbendazim in water via photo-Fenton in raceway pond reactor: assessment of acute toxicity and transformation products. Environ Sci Pollut Res 26:4324-4336. https://doi.org/ 10.1007/s11356-018-2130-z

De la Obra JI, López JLC, Ibáñez GR, García BE, Pérez JAS (2019) Kinetic assessment of antibiotic resistant bacteria inactivation by solar photo-Fenton in batch and continuous flow mode for wastewater reuse. Water Res 159:184-191. https://doi.org/10.1016/j. watres.2019.04.059

Esteban García B, Rivas G, Arzate S, Sánchez Pérez JA (2018) Wild bacteria inactivation in WWTP secondary effluents by solar photoFenton at neutral $\mathrm{pH}$ in raceway pond reactors. Catal Today 313:7278. https://doi.org/10.1016/j.cattod.2017.10.031

Fang GD, Dionysiou DD, Wang Y, Al-Abed SR, Zhou DM (2012) Sulfate radical-based degradation of polychlorinated biphenyls: effects of chloride ion and reaction kinetics. J Hazard Mater 227-228: 394-401. https://doi.org/10.1016/j.jhazmat.2012.05.074

Feng L, Peillex-Delphe C, Lv C, Wang D, Giannakis S, Pulgarin C (2020) Employing bacterial mutations for the elucidation of photoFenton disinfection: focus on the intracellular and extracellular inactivation mechanisms induced by UVA and $\mathrm{H} 2 \mathrm{O} 2$. Water Res 182: 116049. https://doi.org/10.1016/j.watres.2020.116049 
Fiorentino A, Esteban B, Garrido-Cardenas JA, Kowalska K, Rizzo L, Aguera A, Pérez JAS (2019) Effect of solar photo-Fenton process in raceway pond reactors at neutral $\mathrm{pH}$ on antibiotic resistance determinants in secondary treated urban wastewater. J Hazard Mater 378: 120737. https://doi.org/10.1016/j.jhazmat.2019.06.014

Freitas AM, Rivas G, Campos-Mañas MC, Casas López JL, Agüera A, Sánchez Pérez JA (2017) Ecotoxicity evaluation of a WWTP effluent treated by solar photo-Fenton at neutral $\mathrm{pH}$ in a raceway pond reactor. Environ Sci Pollut Res 24:1093-1104. https://doi.org/10. 1007/s11356-016-7101-7

Giannakis S (2017) Analogies and differences among bacterial and viral disinfection by the photo-Fenton process at neutral $\mathrm{pH}$ : a mini review. Environ Sci Pollut Res 25:27676-27692. https://doi.org/10. 1007/s11356-017-0926-x

Giannakis S, Le TTM, Entenza JM, Pulgarin C (2018) Solar photoFenton disinfection of 11 antibiotic-resistant bacteria (ARB) and elimination of representative AR genes. Evidence that antibiotic resistance does not imply resistance to oxidative treatment. Water Res 143:334-345. https://doi.org/10.1016/j.watres.2018.06.062

Giannakis S, Voumard M, Grandjean D, Magnet A, De Alencastro LF, Pulgarin C (2016) Micropollutant degradation, bacterial inactivation and regrowth risk in wastewater effluents: influence of the secondary (pre)treatment on the efficiency of advanced oxidation processes. Water Res 102:505-515. https://doi.org/10.1016/j.watres.2016. 06.066

Giannakis S, Watts S, Rtimi S, Pulgarin C (2017) Solar light and the photo-Fenton process against antibiotic resistant bacteria in wastewater: a kinetic study with a streptomycin-resistant strain. Catal Today 313:86-93. https://doi.org/10.1016/j.cattod.2017.10.033

ISO (2007) Water quality - determination of the inhibitory effect of water samples on the light emission of Vibrio fischeri (luminescent bacteria test) - part 3: method using freeze-dried bacteria. Examination of biological properties of water

ISO (1998) ISO 6332:1988 water quality - determination of iron spectrometric method using 1,10-phenantroline

Klamerth N, Malato S, Agüera A, Fernández-Alba A (2013) PhotoFenton and modified photo-Fenton at neutral $\mathrm{pH}$ for the treatment of emerging contaminants in wastewater treatment plant effluents: a comparison. Water Res 47:833-840. https://doi.org/10.1016/j. watres.2012.11.008

Klamerth N, Malato S, Maldonado MI, Agüera A, Fernández-Alba A (2010) Modified photo-Fenton for degradation of emerging contaminants in municipal wastewater effluents. Catal Today 161:241-246. https://doi.org/10.1016/j.cattod.2010.10.074

Kwon M, Kim S, Yoon Y, Jung Y, Hwang TM, Lee J, Kang JW (2015) Comparative evaluation of ibuprofen removal by UV/H2O2 and UV/S2O82- processes for wastewater treatment. Chem Eng J 269: 379-390. https://doi.org/10.1016/j.cej.2015.01.125

Lian L, Yao B, Hou S, Fang J, Yan S, Song W (2017) Kinetic study of hydroxyl and sulfate radical-mediated oxidation of pharmaceuticals in wastewater effluents. Environ Sci Technol 51:2954-2962. https:// doi.org/10.1021/acs.est.6b05536

Liang C, Huang CF, Mohanty N, Kurakalva RM (2008) A rapid spectrophotometric determination of persulfate anion in ISCO. Chemosphere 73:1540-1543. https://doi.org/10.1016/j. chemosphere.2008.08.043

Litter MI, Candal RJ, Meichtry JM (2017) Advanced oxidation technologies: sustainable solutions for environmental treatments. CRC Press

Malato S, Fernández-Ibáñez P, Maldonado MI, Blanco J, Gernjak W (2009) Decontamination and disinfection of water by solar photocatalysis: recent overview and trends. Catal Today 147:1-59. https://doi.org/10.1016/j.cattod.2009.06.018

Marcelino RBP, Queiroz MTA, Amorim CC, Leão MMD, BritesNóbrega FF (2014) Solar energy for wastewater treatment: review of international technologies and their applicability in Brazil.
Environ Sci Pollut Res 22:762-773. https://doi.org/10.1007/ s11356-014-3033-2

Michael SG, Michael-Kordatou I, Beretsou VG, Jäger T, Michael C, Schwartz T, Fatta-Kassinos D (2019) Solar photo-Fenton oxidation followed by adsorption on activated carbon for the minimisation of antibiotic resistance determinants and toxicity present in urban wastewater. Appl Catal B Environ 244:871-880. https://doi.org/ 10.1016/j.apcatb.2018.12.030

Miralles-Cuevas S, Darowna D, Wanag A, Mozia S, Malato S, Oller I (2017) Comparison of UV/H2O2, UV/S2O82-, solar/Fe(II)/H2O2 and solar/Fe(II)/S2O $82-$ at pilot plant scale for the elimination of micro-contaminants in natural water: an economic assessment. Chem Eng J 310:514-524. https://doi.org/10.1016/j.cej.2016.06. 121

Munir M, Wong K, Xagoraraki I (2011) Release of antibiotic resistant bacteria and genes in the effluent and biosolids of five wastewater utilities in Michigan. Water Res 45:681-693. https://doi.org/10. 1016/j.watres.2010.08.033

Nogueira RFP, Oliveira MC, Paterlini WC (2005) Simple and fast spectrophotometric determination of $\mathrm{H} 2 \mathrm{O} 2$ in photo-Fenton reactions using metavanadate. Talanta 66:86-91. https://doi.org/10.1016/j. talanta.2004.10.001

Norte THO, Marcelino RBP, Moreira RPL, Binatti I, Starling MCVM, Amorim CC, Pereira ES, Rocha WR, Lago RM (2018) ESI-MS, UV-Vis, and theoretical investigation of $\mathrm{Fe} 3+$-amoxicillin complexation during coagulation. J Environ Eng (United States) 144: 1-7. https://doi.org/10.1061/(ASCE)EE.1943-7870.0001314

Novo A, André S, Viana P, Nunes OC, Manaia CM (2013) Antibiotic resistance, antimicrobial residues and bacterial community composition in urban wastewater. Water Res 47:1875-1887. https://doi. org/10.1016/j.watres.2013.01.010

Novo A, Manaia CM (2010) Factors influencing antibiotic resistance burden in municipal wastewater treatment plants. Appl Microbiol Biotechnol 87:1157-1166. https://doi.org/10.1007/s00253-0102583-6

O'Neill J (2014) Antimicrobial resistance: tackling a crisis for the health and wealth of nations the review on antimicrobial resistance chaired

Olmez-Hanci T, Arslan-Alaton I, Dursun D (2014) Investigation of the toxicity of common oxidants used in advanced oxidation processes and their quenching agents. J Hazard Mater 278:330-335. https:// doi.org/10.1016/j.jhazmat.2014.06.021

Papić S, Vujević D, Koprivanac N, Šinko D (2009) Decolourization and mineralization of commercial reactive dyes by using homogeneous and heterogeneous Fenton and UV/Fenton processes. J Hazard Mater 164:1137-1145. https://doi.org/10.1016/j.jhazmat.2008.09. 008

Pei R, Kim SC, Carlson KH, Pruden A (2006) Effect of river landscape on the sediment concentrations of antibiotics and corresponding antibiotic resistance genes (ARG). Water Res 40:2427-2435. https://doi.org/10.1016/j.watres.2006.04.017

Poole AJ (2004) Treatment of biorefractory organic compounds in wool scour effluent by hydroxyl radical oxidation. Water Res 38:34583464. https://doi.org/10.1016/j.watres.2004.06.001

Ribeiro AR, Nunes OC, Pereira MFR, Silva AMT (2015) An overview on the advanced oxidation processes applied for the treatment of water pollutants defined in the recently launched directive 2013/39/EU. Environ Int 75:33-51. https://doi.org/10.1016/j. envint.2014.10.027

Ribeiro ARL, Moreira NFF, Li Puma G, Silva AMT (2019) Impact of water matrix on the removal of micropollutants by advanced oxidation technologies. Chem Eng J 363:155-173. https://doi.org/10. 1016/j.cej.2019.01.080

Rivas G, Carra I, García Sánchez JL, Casas López JL, Malato S, Sánchez Pérez JA (2015) Modelling of the operation of raceway pond reactors for micropollutant removal by solar photo-Fenton as a function 
of photon absorption. Appl Catal B-Environ 178:210-217. https:// doi.org/10.1016/j.apcatb.2014.09.015

Rizzo L, Manaia C, Merlin C, Schwartz T, Dagot C, Ploy MC, Michael I, Fatta-Kassinos D (2013) Urban wastewater treatment plants as hotspots for antibiotic resistant bacteria and genes spread into the environment: a review. Sci Total Environ 447:345-360. https://doi. org/10.1016/j.scitotenv.2013.01.032

Roccaro P, Sgroi M, Vagliasindi F (2013) Removal of xenobiotic compounds from wastewater for environment protection: treatment processes and costs. Chem Eng Trans 32:505-510. https://doi.org/10. 3303/CET1332085

Rodríguez-Chueca J, Giannakis S, Marjanovic M, Kohantorabi M, Gholami MR, Grandjean D, de Alencastro LF, Pulgarín C (2019a) Solar-assisted bacterial disinfection and removal of contaminants of emerging concern by Fe2+-activated HSO5- vs. S2O82- in drinking water. Appl Catal B Environ 248:62-72. https://doi.org/10.1016/j. apcatb.2019.02.018

Rodríguez-Chueca J, Guerra-Rodríguez S, Raez JM, López-Muñoz MJ, Rodríguez E (2019b) Assessment of different iron species as activators of S2O82- and HSO5- for inactivation of wild bacteria strains. Appl Catal B Environ 248:54-61. https://doi.org/10.1016/j.apcatb. 2019.02.003

Serna-Galvis EA, Troyon JA, Giannakis S, Torres-Palma RA, Carena L, Vione D, Pulgarin C (2019a) Kinetic modeling of lag times during photo-induced inactivation of $\mathrm{E}$. coli in sunlit surface waters: unraveling the pathways of exogenous action. Water Res 163: 114894. https://doi.org/10.1016/j.watres.2019.114894

Serna-Galvis EA, Vélez-Peña E, Osorio-Vargas P, Jiménez JN, SalazarOspina L, Guaca-González YM, Torres-Palma RA (2019b) Inactivation of carbapenem-resistant Klebsiella pneumoniae by photo-Fenton: residual effect, gene evolution and modifications with citric acid and persulfate. Water Res 161:354-363. https://doi.org/ 10.1016/j.watres.2019.06.024

Sharma VK, Johnson N, Cizmas L, McDonald TJ, Kim H (2016) A review of the influence of treatment strategies on antibiotic resistant bacteria and antibiotic resistance genes. Chemosphere 150:702-714. https://doi.org/10.1016/j.chemosphere.2015.12.084

Starling MCVM, Amorim CC, Leão MMD (2019a) Occurrence, control and fate of contaminants of emerging concern in environmental compartments in Brazil. J Hazard Mater 372:17-36. https://doi. org/10.1016/j.jhazmat.2018.04.043

Starling MCVM, Souza PP, Le Person A, Amorim CC, Criquet J (2019b) Intensification of $\mathrm{UV}-\mathrm{C}$ treatment to remove emerging contaminants by $\mathrm{UV}-\mathrm{C} / \mathrm{H} 2 \mathrm{O} 2$ and $\mathrm{UV}-\mathrm{C} / \mathrm{S} 2 \mathrm{O} 82-$ : susceptibility to photolysis and investigation of acute toxicity. Chem Eng J 376:120856. https://doi.org/10.1016/j.cej.2019.01.135

Tiedeken EJ, Tahar A, McHugh B, Rowan NJ (2017) Monitoring, sources, receptors, and control measures for three European Union watch list substances of emerging concern in receiving waters - a 20 year systematic review. Sci Total Environ 574:1140-1163. https:// doi.org/10.1016/j.scitotenv.2016.09.084

Wacławek S, Lutze HV, Grübel K, Padil VVT, Černík M, Dionysiou DD (2017) Chemistry of persulfates in water and wastewater treatment: a review. Chem Eng J 330:44-62. https://doi.org/10.1016/j.cej. 2017.07.132

Wang Y, Roddick FA, Fan L (2017) Direct and indirect photolysis of seven micropollutants in secondary effluent from a wastewater lagoon. Chemosphere 185:297-308. https://doi.org/10.1016/j. chemosphere.2017.06.122

WATER T (2016) Improved Pou disinfection with UVC LEDs 2016 https://www.watertechonline.com/improved-pou-disinfection-withuvc-leds/. Accessed 08 January 2017

Wordofa DN, Walker SL, Liu H (2017) Sulfate radical-induced disinfection of pathogenic Escherichia coli O157:H7 via iron-activated persulfate. Environ Sci Technol Lett 4:154-160. https://doi.org/10. 1021/acs.estlett.7b00035

Xiao R, Liu K, Bai L, Minakata D, Seo Y, Kaya Göktaş R, Dionysiou DD, Tang CJ, Wei Z, Spinney R (2019) Inactivation of pathogenic microorganisms by sulfate radical: present and future. Chem Eng J 371:222-232. https://doi.org/10.1016/j.cej.2019.03.296

Yuan QB, Guo MT, Yang J (2015) Fate of antibiotic resistant bacteria and genes during wastewater chlorination: implication for antibiotic resistance control. PLoS One 10:1-11. https://doi.org/10.1371/ journal.pone. 0119403

Publisher's note Springer Nature remains neutral with regard to jurisdictional claims in published maps and institutional affiliations. 